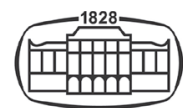

AKADÉMIAI KIADÓ

\title{
Follow the Rivers?
}

\section{Group identity, interactions and the role of rivers in late Hallstatt southern Pannonia}

\section{Archaeologiai Értesítő}

$146(2021) 43-64$

DOI:

10.1556/0208.2021.00017

(c) 2021 The Author

\section{STUDY}

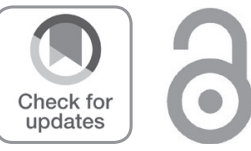

* Corresponding author.

E-mail: soos.bence@mnm.hu

\section{Bence Soós* (iD}

Hungarian National Museum, Department of Archaeology; 1088 Budapest, Múzeum körút 14-16; Eötvös Loránd University, Institute of Archaeological Sciences; 1088 Budapest, Múzeum körút 4/B

Received: 22 June 2021 • Accepted: 18 July 2021

\section{ABSZTRAKT}

Jelen tanulmány célja annak vizsgálata hálózatelemzési szempontok érvényre juttatása mellett, hogy a Kárpát-medence délnyugati régiójában a késő Hallstatt-időszak közösségei közötti interakciókat és kommunikációt milyen módon befolyásolták és szervezték a térség nagyobb folyói.

KULCSSZAVAK

késő Hallstatt-periódus, hálózatok

\section{ABSTRACT}

With the help of basic network models, this paper sets out to assess the role of major rivers played in influencing and organizing interactions and communication between late Hallstatt-period communities in the south-western part of the Carpathian Basin.

\section{KEYWORDS}

late Hallstatt period, networks

\section{INTRODUCTION}

The two graves found near today's Beremend in Baranya County are of pivotal importance when discussing the communities of the late $6^{\text {th }}$ and $5^{\text {th }}$ centuries BC in southern Transdanubia ever since they were discovered. They were the first cornerstones of the notion that after the $6^{\text {th }}$ century BC upheaval, the communities in southern Transdanubia had integrated into the complex of the southern Pannonian late Hallstatt group, at least as far as the burial customs and characteristic funerary representation is concerned. ${ }^{1}$ At the same time, they provide evidence for the re-emerging contacts between the communities in southern Transdanubia and the Dolenjska region in the late $6^{\text {th }}$ and $5^{\text {th }}$ centuries $\mathrm{BC},{ }^{2}$ as well as for the new elite which is supposed to have forged and maintained these contacts. ${ }^{3}$ With the help of basic network models, in the followings I investigate how contacts and interactions might have been forged and what motivated the creation of such ties between the communities.

\section{THE FORMATION OF A NEW ELITE}

It is widely accepted that the first half of the $6^{\text {th }}$ century BC saw a fundamental cultural and social transformation in the western part of the Carpathian Basin. ${ }^{4}$ Although the exact causes

\footnotetext{
${ }^{1}$ Majnarić-Pandžić 1973; Guštin-TeržAn 1977, 80

${ }^{2}$ Jerem 1974, 238; Dular-Tecco Hvala 2007, 232.

${ }^{3}$ Babić-Palavestra 1999; Ljuština 2010, 66.

${ }^{4}$ TeRŽAN 1998, 521; EgG 2013.
} 
for this process are still debated, its signs in the archaeological record are clear. The custom of building large funerary mounds and most fortified hilltop settlements seems to have been abandoned. ${ }^{5}$ All of this suggest that the "crisis" affected primarily the former elite. ${ }^{6}$ Their assumed downfall also brought with it either the disintegration or weakening of the interregional communicational ties between the communities in Transdanubia and the adjacent areas $^{7}$ and hence it also led to the disintegration of the loosely defined and heterogeneous cultural milieu of the Eastern Hallstatt zone.

However, after the so-called crisis of the Eastern Hallstatt zone, especially from the late $6^{\text {th }}$ century BC onward, similarly to the Dolenjska region in today's Slovenia, the western half of the Carpathian Basin also saw a period of consolidation. ${ }^{9}$ Evidence for this is provided by several settlements such as Sopron-Krautacker, ${ }^{10}$ Sé-Doberdó, ${ }^{11}$ Zbelava $^{12}$ and Szajk, ${ }^{13}$ just to name a few. In addition, the funerary data available in southern Transdanubia, eastern Slavonia and the Srem region strongly suggests that in this period, a new elite emerged. ${ }^{14}$

The most outstanding and unequivocal evidence for this new elite comes from the area surrounding today's Sremska Mitrovica. In 1901 several items allegedly belonging to a burial came to light during construction works at the so-called Fabrika tanina site. ${ }^{15}$ Among the objects, we find the most characteristic elements of late Hallstatt-period attires in the southern Pannonian region, i.e., an astragal belt and Certosa fibulae. Based on the brooches, the assemblage dates to the late $6^{\text {th }}$ and early $5^{\text {th }}$ century BC. ${ }^{16}$ Although the aforementioned items have been of great importance in defining the cultural framework of the Srem district and the surrounding regions during the latest stage of the Early Iron Age, the most notable item among the finds is a necklace made of gold beads with filigree decoration and tubes of gold wire. ${ }^{17}$ Its significance stems from the fact that necklaces comprising similar beads made of precious metals are frequently present among the items found in princely graves of the Central and Southern Balkans. ${ }^{18}$ One can argue that the necklace links

${ }^{5}$ The picture of the abandonement of hilltop settlements, however, is far from clear. For instance, based on the preliminary results of their excavation, E. Marton and J. Regenye suggested that Tihany-Óvár had been occupied during the $\mathrm{Ha}$ D3/La Tène A transitional period. Marton-Regenye 2005, 52.

${ }^{6}$ EgG 2010, 63; EgG 2013.

${ }^{7}$ Dular-Tecco Hvala 2007, 232.

${ }^{8}$ Metzner-Nebelsick 2017, 369-370.

${ }^{9}$ TeržAn 1998, 521; KovačEvić 2007, 105; KovačEvić 2008, 66.

${ }^{10}$ JEREM 1981.

${ }^{11}$ GÁL-MOLNÁr 2004.

${ }^{12}$ KovaČEvić 2007; KovaČEvić 2008.

${ }^{13}$ GÁti 2009; GÁti 2014.

${ }^{14}$ Babić-Palavestra 1999.

${ }^{15}$ BRUNŠMID 1902, 75.

${ }^{16}$ Potrebica-Dizdar 2014a, 153.

${ }^{17}$ Potrebica-Dizdar 2014a, 153.

${ }^{18}$ Dmitrović-Ljustina 2020，106; Potrebica-Dizdar 2014a, 153. the Sremska Mitrovica burial to the most opulent late Early Iron Age assemblages of the Central and Southern Balkans to a certain extent, ${ }^{19}$ and thus, to the upheaval of the elite's appreciation of precious metals in the $6^{\text {th }}$ century BC. ${ }^{20}$

The existence of this new elite around today's Sremska Mitrovica is reflected in further finds. In 1960 fragments of an Illyrian helmet of the III A2-a type came to light from the river Sava near the Šećerana site along the riverbank. ${ }^{21}$ Unfortunately, due to lacking information about the exact context and possible associated finds, it cannot be decided whether it was part of a grave assemblage or it, say, was deposited as a votive offering. Neither can be its chronological position easily defined, but dating it to the late $6^{\text {th }}$ and the $5^{\text {th }}$ century BC seems feasible. ${ }^{22}$ Since Illyrian-type helmets were essential elements of the warrior representation in the western Balkans in the late $6^{\text {th }}$ and $5^{\text {th }}$ centuries $\mathrm{BC}$ and signalled a certain status, ${ }^{23}$ it is also fair to assume that in the case of the Sremska Mitrovica example this prestigious item could have also been associated with a local elite.

In addition, in 1978 a bronze situla came to light by chance, possibly in the area of the cellulose plant southeast of the town along the banks of the Sava, ${ }^{24}$ possibly near the sugar refinery where the helmet is supposed to have been found. As it was pointed out by P. Medović, it is highly probable that the situla originates from the Dolenjska region, ${ }^{25}$ and based on M. Jereb's recent assessment of the bronze vessels in Slovenia the situla from Sremska Mitrovica can easily be assigned to variant 3.B1a. Since most such vessels came to light from graves dated to the Negova horizon in terms of the relative chronological framework of the Dolenjska group, ${ }^{26}$ it is reasonable to date the situla accordingly, i.e. to the second half of the $5^{\text {th }}$ and the beginning of the subsequent century. Thus, it is somewhat younger than the golden necklace and the Illyrian-type helmet, however, this specimen is still worth taking into account here.

These items display a certain dichotomy. The Illyriantype helmet and the golden necklace along with several other pieces of jewellery made of precious metal from the region indicate the significant role of southern influences in shaping the forms of representation of the newly emerging elite. ${ }^{27}$ Contacts of this prominent group, nevertheless, do not confine to ties with regions lying to the south of the Srem region. As already mentioned, searching the origin of the bronze situla from Sremska Mitrovica in the Dolenjska region of today's Slovenia is more than reasonable. Similarly, there is hardly any doubt that the Certosa fibulae should also be

\footnotetext{
${ }^{19}$ ПАЛАВЕСТРА 1984, 67.

${ }^{20}$ VAsić 2001, 23.

${ }^{21}$ VASIĆ $1983,76$.

${ }^{22}$ Vasić 2010, 40-41; Blečić Kavur-Pravidur 2012, 83-84; BLEČIĆ KAVUR 2017, 52.

${ }^{23}$ TeržAn 1995, 86; Blečić 2007, 92.

${ }^{24}$ Медовић 1990, 159.

${ }^{25}$ Медовит 1990, 162; Medović-HÄNSEl 2006, 495.

${ }^{26}$ Jereb 2016, 50.

${ }^{27}$ Potrebica-Dizdar 2014a.
} 
directly or indirectly of western origin. ${ }^{28}$ As a result, one can see these items as evidence for the long-ranging contacts the elite (re-)established and maintained in the late $6^{\text {th }}$ and the $5^{\text {th }}$ century BC. ${ }^{29}$

Evidence for this new prominent stratum in the southern part of the Carpathian Basin and for its aspiration to be involved in an interregional contact network, however, does not confine to the Srem region. Furthermore, it provides additional examples of the pattern seen in the case of the Sremska Mitrovica finds, i.e. that items of both western and southern origin appeared in the representational sets of the newly emerging elite. In 1962 near Beremend workers found the remains of what is now believed to be two distinct inhumation graves in a sand quarry. ${ }^{30}$ Both yielded spectacular assemblages containing various types of jewellery and elements of attire (Fig. 1), including items that are indicative of both western and southern contacts of the late $6^{\text {th }}$ and early $5^{\text {th }}$-century communities who lived near today's Beremend. Besides the numerous Certosa fibulae which adorned the attire of both interred individuals, a so-called sceptre (Fig. 1,5) made of a thin bronze sheet suggests that members of the community burying their dead in the burial ground near Beremend were connected to the Iron Age groups of southeastern Slovenia through a web of interactions and exchange. ${ }^{31}$ On the other hand, the graves yielded items that link them to a certain extent to the central Balkans. Such items are the Novi Pazar type silver fibulae ${ }^{32}$ (Fig. 1, 3-4) from Grave 2 and the silver foil bead decorated with granulation technique ${ }^{33}$ found among the grave goods of Grave 1 (Fig. 1, 9) ${ }^{34}$ Now, the belt plates made of a bronze sheet with openwork decoration (Fig. 1, 1-2), being among the latest ones of their kind, support the second observation insofar as the main distribution area of such items lies between the rivers Velika Morava and Isker. ${ }^{35}$

The sites near Sremska Mitrovica and Beremend are tied together by the directions of the contacts their assemblages suggest, and even by some of the finds. However, another similarity deserves attention. Although the exact contexts and provenience of the finds from Sremska Mitrovica are largely unknown, the information at hand indicates that they have been found along the banks of the Sava River. Nowadays, the river Drava flows some 8.2 kilometres away from the Iron Age burial ground of Beremend and the site is currently surrounded by vast crop fields, however, the situation used to be radically different before the major river regulations in the $19^{\text {th }}$ century. Based on the accounts of the 1827 flood, the

\footnotetext{
${ }^{28}$ TeržAn 1977a, 375.

${ }^{29}$ Dular-Tecco Hvala 2007, 232.

${ }^{30}$ JEREM 1973.

${ }^{31}$ JEREM 1974.

${ }^{32}$ A fibula of this type appears in Sremska Mitrovica, too (VAsić 1999, 78).

${ }^{33}$ This shows great similarity with the silver foil beads found among the items of the Kruševica assemblage (СРејовић-Вүкадин 1983, Tab. 4, 4-6.)

${ }^{34}$ JEREM 1973.

${ }^{35}$ VASIĆ $1971,1$.
}

river Drava breached the dyke system at several points that had only recently been installed causing one of the largest floodings in its recorded history. ${ }^{36}$ The river inundated its entire floodplain even reaching the environs of the modern village Beremend. ${ }^{37}$ Now, if we look at the maps of the Josephinian Land Survey of the Habsburg Empire (17631787), it is apparent that the areas lying to the south of Beremend were regularly inundated before the river regulations (Fig. 2). ${ }^{38}$ The Iron Age cemetery, however, given its position along the edge of a slight elevation must have been spared even in the cases of the most formidable floods, for instance, the one in 1827. Understandably, the burials near Beremend are hardly the most convincing let alone obvious evidence for the intimate relation between waterways and cemeteries of the late Hallstatt period in southern Pannonia. Indeed, I shall address this topic somewhat later, but suffice to say, the site near Beremend fits the pattern.

\section{THE NETWORK OF THE SAVA CORRIDOR}

It is a long-established notion that the river Sava played an essential role in providing a communication route for interaction and exchange between Early Iron Age communities of the southern part of the Carpathian Basin, the southeastern Alpine regions as well as the northwestern Balkans. ${ }^{39}$ It has also been established several times, that the river served as an essential route over which local elites were able to maintain contacts, exchange or trade relations and possibly political alliances during the Early Iron Age. ${ }^{40}$ The example of the Sremska Mitrovica finds indicates that this could have been the case with the newly emerging elite in the late $6^{\text {th }}$ century BC. ${ }^{41}$

In addition, the general importance of this waterway - the Sava corridor ${ }^{42}$ as it has been recently referred to - at that time is reflected by another, more robust body of evidence comprising the Certosa V type fibulae, whose distribution area stretches from Etruria to the Iron Gates. By mapping the occurrences of such fibulae we can see that the Sava played a decisive role in the proliferation of these dress elements east of today's Slovenia. It is, in fact, possible to estimate in terms of sheer numbers how essential the river, or more precisely, the communities living along this waterway

\footnotetext{
${ }^{36}$ Petrić et al. 2019, 109.

${ }^{37}$ BenCs-DÁvid 2016, 43.

${ }^{38}$ Source: mapire.eu (Access: April 1st 2021).

${ }^{39}$ Potrebica 2008, 196.

${ }^{40}$ For instance: EIBNER 2000.

${ }^{41}$ Iron Age communities who lived near today's Sremska Mitrovica were in geographical terms well-suited to maintain contacts with communities to the south through the main communication routes of the Balkans (Potrebica 2008, Fig. 3), hence the golden necklace with the beads decorated in a fashion characteristic to the Balkans (Potrebica-Dizdar 2014a) and the Illyrian helmet originating probably from the southern or the western Balkans (Blečić Kavur-Pravidur 2012, 72).

${ }^{42}$ Blečić Kavur-JAšARević 2016, 226.
} 
A

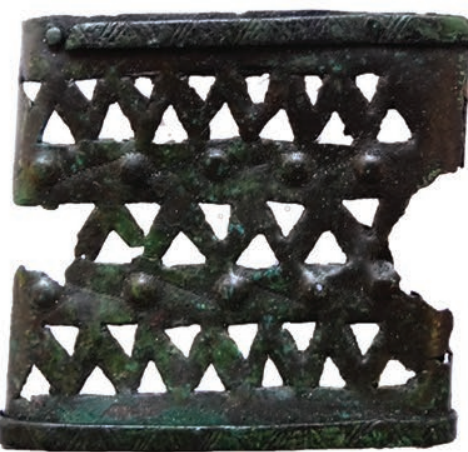

1

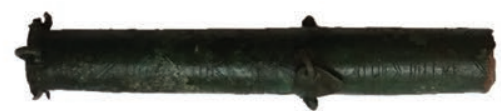

5

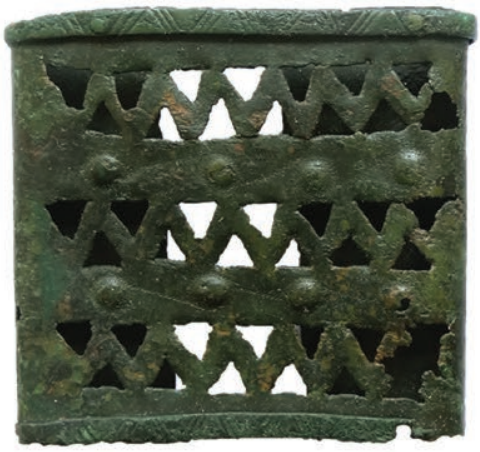

2

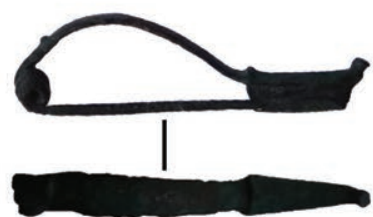

6

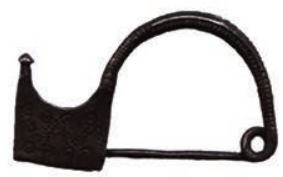

3

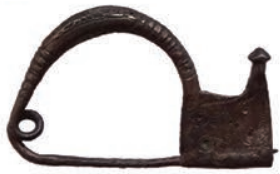

4

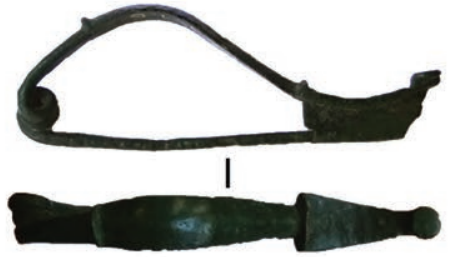

7

B

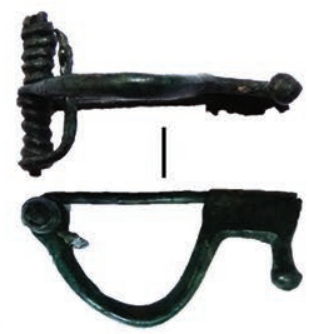

8

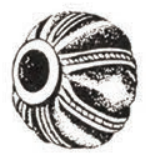

9

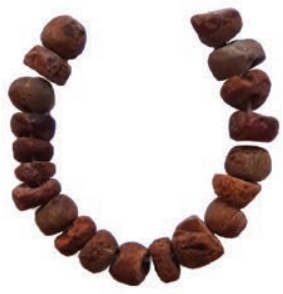

10

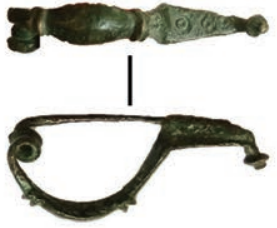

11

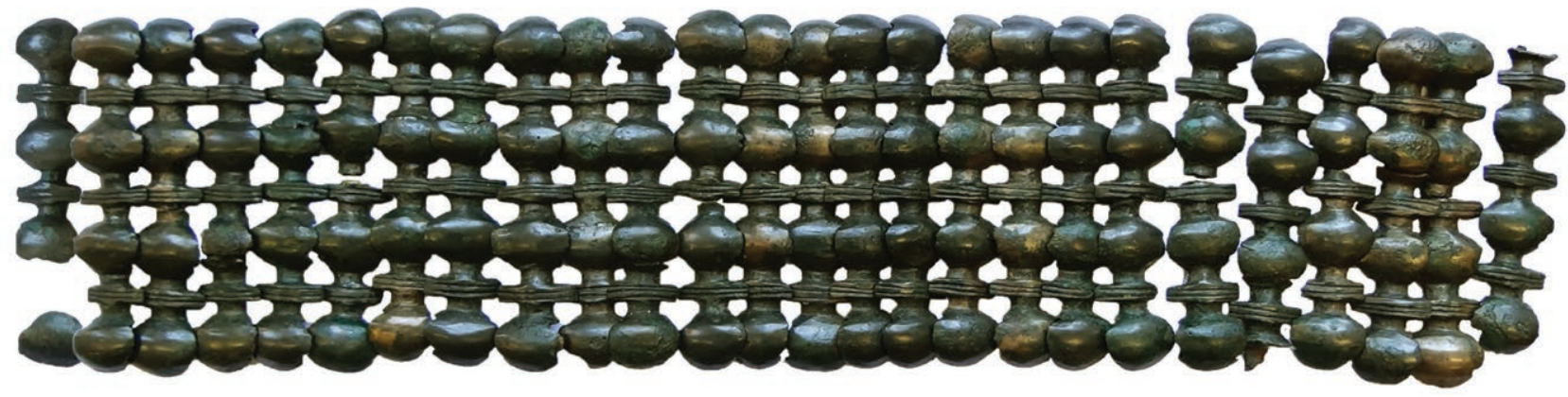

12

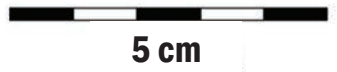

Fig. 1. Selection of the finds recovered from the Beremend burials. A: Grave 2; B: Grave 1. (No. 9: after JeREM 1973, Abb. 5,5)

1. kép. Válogatott tárgyak a beremendi sírok mellékletei közül. A: 2. sír; B: 1. sír. (No. 9: JeREM 1973, Abb. 5,5 után) 


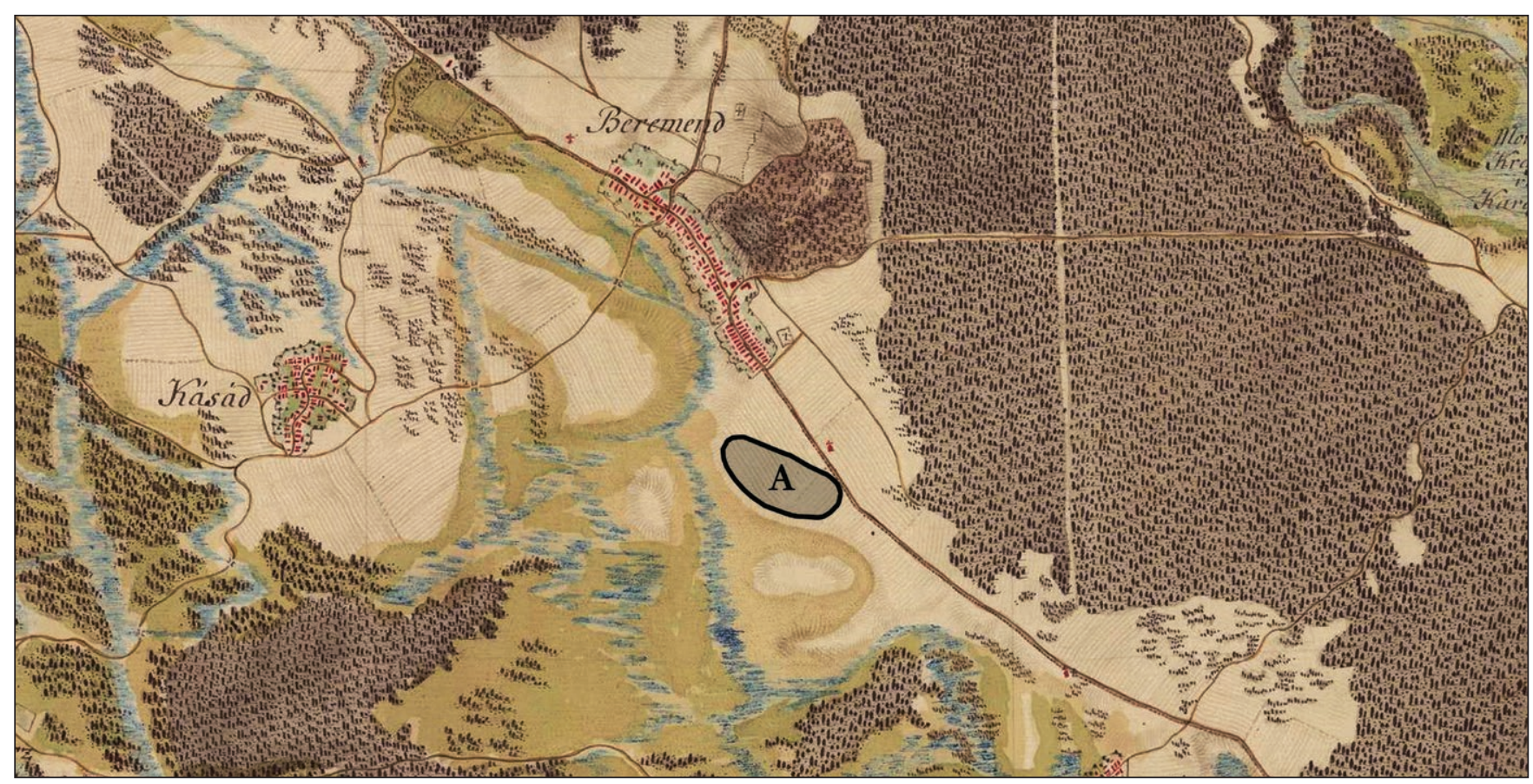

Fig. 2. Environs of the Beremend cemetery on the First Military Survey maps of the Habsburg Empire (1763-1790). Source: mapire.eu (Access: April $1^{\text {st }}$ 2021); MoLnÁR et al. 2014)

2. kép. A beremendi temető környezete a Habsburg Birodalom első katonai felmérésének (1763-1790) térképlapjain. Forrás: mapire.eu (Hozzáférés: 2021. április 01); MoLnÁR et al. 2014

could have been in the distribution of Certosa V type fibulae. At the same time, through the geographical patterns of their distribution, these fibulae allow a slight glimpse into what the network of relations and interactions in which the elites of the communities in southern Pannonia maintained and participated in could have looked like.

Geographical distance could have been a severe constraint of interaction, ${ }^{43}$ and hence it is reasonable to assume that the distribution of products or ideas over large distances took place through interactions and exchanges between local intermediaries, in other words, through actors in close geographical proximity to one another. By applying proximal point analysis to the sites mapped, it is possible to construct with this baseline assumption a hypothetical route network through which the fibulae could have spread. ${ }^{44}$ In this model, the vertices are the sites of Certosa $\mathrm{V}$ brooches and every node is connected to its $k$ nearest neighbour (Fig. 3). I have chosen the smallest $k$ such that a network emerges that includes all sites $(k=4)$.

The significance of the vertices in a network is usually expressed with various centrality measures, among which betweenness centrality stands out as a way of quantifying the importance of the nodes in the communication between other pairs of nodes. ${ }^{45}$ As the table in the above figure suggests, among the nodes of the network, the vertex corresponding to the Sisak site has the largest betweenness centrality value, but this is certainly not the only site situated along the river Sava. Four of the ten largest betweenness centrality scores are associated with sites located along this waterway. Furthermore, two happen to be linked to sites between the Sava and the Danube.

Both of the latter are located in the vicinity of today's Vinkovci. ${ }^{46}$ Unfortunately, the late Hallstatt-period items from these sites are without documented context and have to be considered stray finds, which might indicate certain weaknesses of this model. However, the area and the surroundings of Vinkovci have proven to be essential in understanding the cultural processes of the southern Pannonian region in the period between the late $6^{\text {th }}$ century and the beginning of the $4^{\text {th }}$ century BC. ${ }^{47}$ The burial with a rich set of dress elements found at the Vinkovci-Silos site, a similar assemblage near Novi Jankovci along with the grave finds near Vučedol made it clear that the eastern part of Slavonia shows strong cultural ties towards the Srem region as well as towards southern Transdanubia. ${ }^{48}$ It seems that these ties remained intact during the $5^{\text {th }}$ century BC, indicated by the Vinkovci-Nama and Szentlörinc cemeteries. ${ }^{49}$ The relatively large betweenness centrality value of the Vinkovci-Dren site,

\footnotetext{
${ }^{43}$ Amati et al. 2018, 229; DE Groot 2019, 605.

${ }^{44}$ Östborn-Gerding 2014, 76; Amati et al. 2018, 230-231.

${ }^{45}$ Newman 2010, 185; Estrada-KNight 2015, 152.
}

\footnotetext{
${ }^{46}$ DiZDAR 2019.

${ }^{47}$ Potrebica-Dizdar 2002.

${ }^{48}$ MajNARIĆ-PANDŽIĆ 1973, 39.

${ }^{49}$ MajNARIĆ-PANDŽIĆ 2003, 500.
} 


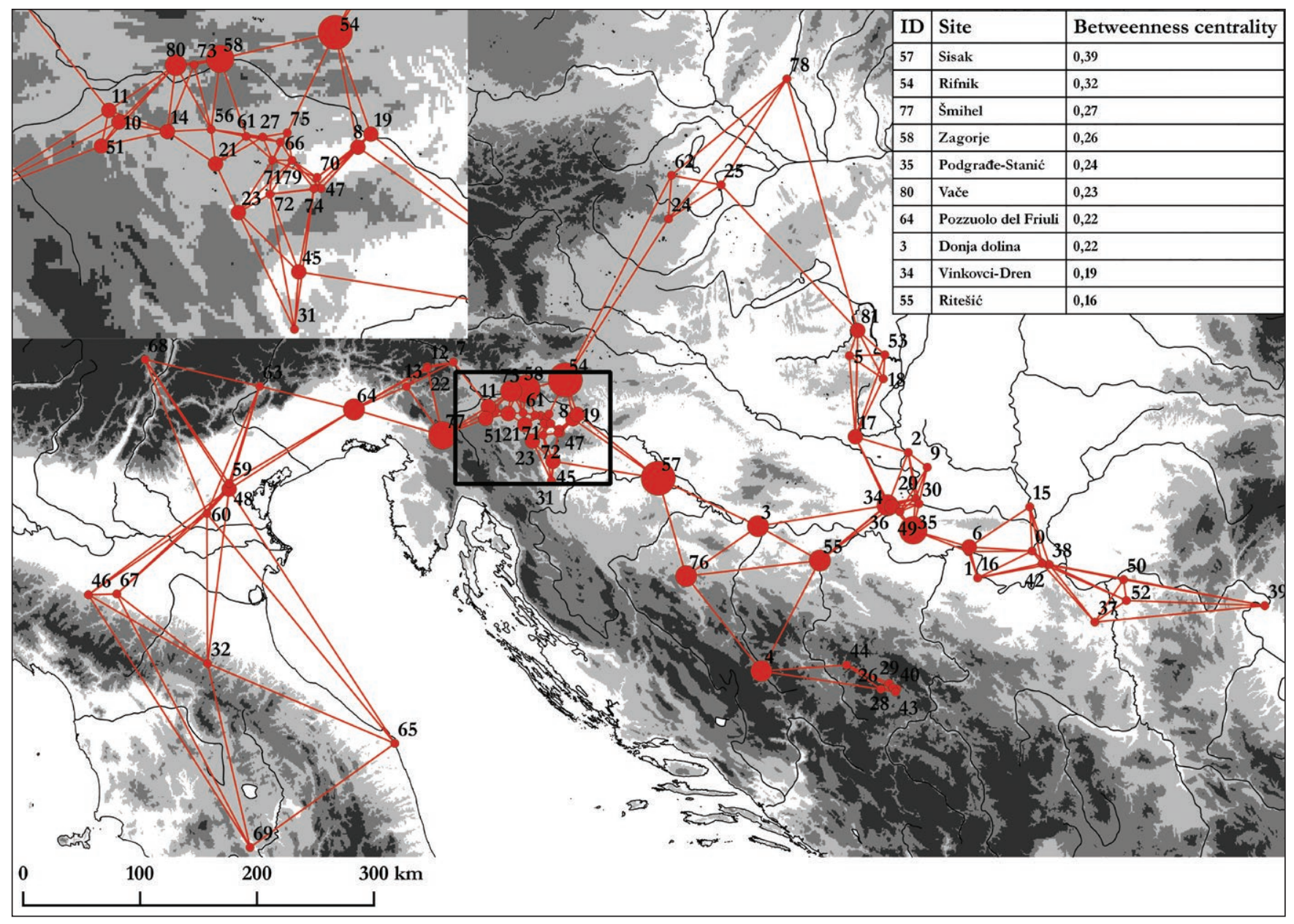

Fig. 3. Spatial network generated with Proximal Point Analysis of the Certosa 5 type fibulae's distribution [k=4]. The size of the nodes is proportional to their betweenness centrality value

3. kép. A Certosa V típusú fibulák elterjedése alapján, pontmintázat elemzéssel létrehozott térbeli hálózat [k=4]. A pontok mérete arányos a hozzájuk kapcsolódó közöttiségi központiság értékkel

or in other words, the significance of the surroundings of Vinkovci in this network, derives partly from the fact that the sites in eastern Slavonia constitute a bridge towards Transdanubia, as far as the network discussed here is considered. $^{50}$

\section{SIMILARITY NETWORKS OF LATE HALLSTATT-PERIOD COMMUNITIES}

It must be acknowledged that the model discussed so far does not provide much more information than a simple distribution map. Although it can be seen that the most likely route for the eastern spread of Certosa V fibulae - and Certosa fibulae in general - followed the river Sava, the re-

${ }^{50}$ The sites of eastern Slavonia and those of the Srem district seem to be hubs of East-West contacts not only in the latest stages of the Hallstatt period, but even earlier, in the Early Iron Age. This is clearly shown by the node concentration of the characteristic motifs of the Basarabi style in named regions (EIBNER 2001). lationships depicted in the model presumably have a rather heterogeneous cultural and social background, as well as cultural, social, and probably transactional subject matter. The reason for this is that the model does not take the archaeological record into account apart from one group of objects and its geographical distribution. For example, it ignores the fact that Certosa V-type fibulae, like other Certosa types, have become defining elements of a characteristic, well-recognized, hybrid dress combination in the southern Pannonian region at the end of the $6^{\text {th }}$ century BC. ${ }^{51}$ That is, in parallel with the emergence of Certosa-type fibulae, a characteristic dress combination appears in southern Pannonia, the prevalence of which is presumably related to the emergence of a new elite in the area during the same period.

The latter assumption is proved by the artefacts from Grave 1 in Beremend, which include elements of the characteristic dress combination: astragal belt, Certosa fibulae (types Ib and 13), glass paste and amber beads (Fig. 1, B). ${ }^{52}$

\footnotetext{
${ }^{51}$ DiZDAR 2020, 205-206.

${ }^{52}$ JEREM 1973, 66-68.
} 
One of the two above-mentioned burials found south of Beremend (Grave 2) contained grave goods that, taking into account the representative patterns of the Dolenjska group in Slovenia and the Central Balkans, suggest an outstanding social status of the deceased. ${ }^{53}$ The two burials in Beremend were located close to each other, with a strictly parallel orientation, ${ }^{54}$ implying that there may have been a close, yet difficult-to-determine social connection between the buried persons. More importantly, however, a silver bead with a granulated decoration has been found among the funerary equipment of Grave 1, the parallels of which can be recognized mainly among objects from the Balkan princely graves. ${ }^{55}$ An important example of a similar assumption is the Sremska Mitrovica burial, in which the combination of an astragal belt and Certosa V type fibulae was complemented by a necklace composed of gold wire coils and gold beads. ${ }^{56}$ Another example is an assemblage recently found during an illegal excavation, probably also from the Szerémség region. ${ }^{57}$ According to the published photo, the ensemble of fibulae, beads and astragal belt segments was complemented by a chain with cylindrical elements made of silver wire, coiled in a characteristic pattern, the analogues of which are present among the objects of the Kruševica assemblage, considered a princely find in the Balkans. ${ }^{58}$

While these examples may give the opposite impression, precious metal jewellery should not be considered a standard element of a characteristic costume or "Beremend-type" burials. ${ }^{59}$ The data listed in the table below confirm the previous statement that the essential elements of this costume are: Certosa fibulae, astragal belt, and glass paste beads. The sites listed in the table represent both the regions to the South and North of Beremend (Tab. 1).

The data listed in the table suggest that the recognized characteristics of the dress combination stem in part from the homogeneity of the cases. The composition of the grave goods containing the costume elements in question shows a high degree of similarity, almost a kind of standardized pattern in the region between the rivers Kapos and Sava, especially if we disregard the typological differences of the

\footnotetext{
${ }^{53}$ Evidence for this assumption is provided by the silver fibulae of the Novi Pazar type, usually associated with high status as far as the Iron Age communities of the Balkans are considered (BLEČIĆ KAVUR-MličEvić-CAPEK 2011, 42); as well as by the so-called sceptre made of a bronze sheet which resembles those of which tend to be associated with burials of high-status individuals in the Dolenjska group (Schumann 2015, 228; Tecco Hvala 2012, 341).

${ }^{54}$ JeREM 1973, Abb. 2.

${ }^{55}$ ПАлАвестра 1984, 67; РотreвiCA-Dizdar 2014a, 156.

${ }^{56}$ According to J. Brunšmid, it cannot be ruled out that the dress was complemented by some amber beads found somewhat later than the above listed items (BRUNŠMID 1902, 75).

${ }^{57}$ Filipović-Vasić 2017, 339.

${ }^{58}$ СРЕЈовИТ-ВҮКАДИН 1988, Sl. 2.

${ }^{59}$ Soós 2020, 417.
}

Certosa fibulae. ${ }^{60}$ The similarity of the assemblages found in the graves can be quantified using several similarity measures. In the present case, the composition of the funerary equipment is determined with the help of the so-called Jaccard Index, which is the quotient of the intersection and union of the sets of types found in the two graves.

Based on the sites presented, the characteristic "Beremend-type" dress combination appears at the end of the $6^{\text {th }}$ century BC, in parallel with, and presumably not independently of, the emergence of the supposed elite behind the finds from Beremend and Sremska Mitrovica. It is uncertain, however, to speak of elites in cases when these easily identifiable, high-prestige objects are missing from the characteristic dress elements. Another question is how to identify the elite that organizes long-distance relations north of Beremend. Going further, can we tie to the prominent strata of local communities the individuals who were buried with this characteristic costume, and especially the astragal belts?

Regarding these issues, M. Dizdar and A. Tonc caution against individuals buried with astragal belts necessarily being counted among the elites of communities. ${ }^{61}$ Answers to these questions are also difficult to formulate because only a handful of grave finds came to light from the $6^{\text {th }}-4^{\text {th }}$ centuries $\mathrm{BC}$ in the area between Lake Balaton and the Sava, and most of them are known from a highly restricted context. No example can be mentioned in which it could reasonably be assumed that the entire cemetery was excavated. ${ }^{62}$

Currently, the second largest excavated late Hallstatt-period cemetery north of the Drava is located at the Alsónyék site. ${ }^{63}$ Among the late Hallstatt burials identified in 2008 and 2009, two contained essential elements of the characteristic costume, giving an exceptional opportunity to examine the question raised in the context of a - partially excavated cemetery, taking several factors into account (Fig. 5).

In the diagram showing the extent of the burials ${ }^{64}$ and the number of grave goods ${ }^{65}$ in the Alsónyék cemetery, two groups are distinguished based on the latter. In one group the number of objects does not exceed three, in contrast, there is a group of burials to which more than six objects appear.

${ }^{60}$ Based on well-documented graves with the characteristic attire, Certosa fibulae, even of different types, tend to be worn in similar numbers and in similar arrangement. Hence, it cannot be ruled out that the clothes they held together might have been fashioned similarly.

${ }^{61}$ DizDar-Tonc 2018, 58.

${ }^{62}$ Currently, there is one entirely excavated cemetery in the region and period under consideration, in Szentlörinc, Baranya County, Hungary. However, not one burial there contained the characteristic dress elements (JEREM 1968).

${ }^{63}$ Soós 2021.

${ }^{64}$ In addition to the grave goods, the dimensions, even the area of the graves, are also worth taking into account when dealing with the question of inequality based on funerary data (Yu et al. 2019).

${ }^{65}$ The components of the belts and necklaces were recorded in the database on a case-by-case basis. In the case of urn burials, I also included the vessel containing the ashes among the grave goods. 


\begin{tabular}{|c|c|c|c|c|c|c|c|c|c|c|c|c|c|c|}
\hline 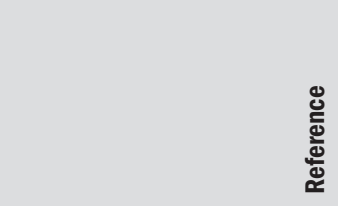 & 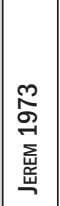 & 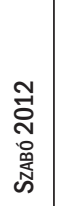 & 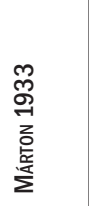 & 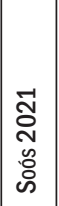 & 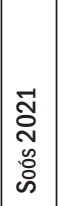 & $\begin{array}{l}\overrightarrow{0} \\
\text { 志 } \\
\text { s. }\end{array}$ & 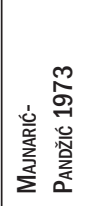 & 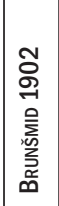 & 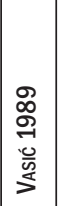 & 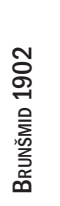 & 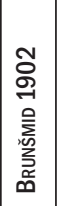 & 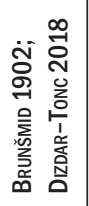 & 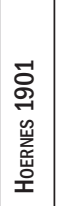 & 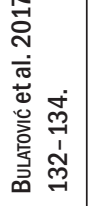 \\
\hline sueəads & 0 & 0 & 0 & 0 & 0 & 0 & 0 & 0 & 0 & $\circ$ & 0 & 0 & $\sim$ & 0 \\
\hline әңци иохן & 0 & -1 & 0 & 0 & 0 & 0 & 0 & 0 & 0 & o & 0 & o & o & 0 \\
\hline ริй әzиолg & 0 & 0 & 0 & 0 & 0 & $\rightarrow$ & 0 & 0 & 0 & 0 & 0 & -4 & 0 & 0 \\
\hline Kä\#०d & 0 & 0 & 0 & -1 & -1 & 0 & 0 & 0 & 0 & 0 & 0 & 0 & 0 & -1 \\
\hline ночм-әриц्dS & 0 & 0 & 0 & 0 & 0 & 0 & 0 & 0 & 0 & 0 & 0 & 0 & 0 & n \\
\hline speəq әəłsed sselפ & $\stackrel{\sim}{\infty}$ & q & $\stackrel{m}{m}$ & is & $\Rightarrow$ & ని & A & 0 & ล & $\hat{\sigma}$ & + & $\stackrel{\infty}{\underset{J}{+}}$ & 0 & $\circ$ \\
\hline speəq дәqü & $\underset{9}{9}$ & 0 & 0 & N & -1 & $m$ & 0 & 0 & -1 & $\circ$ & 0 & ○ & 0 & $\infty$ \\
\hline |еұәш sno!כә્યd to әреш speəg & -1 & o & 0 & 0 & 0 & $\sigma$ & 0 & $\theta$ & 0 & o & 0 & o & o & $\stackrel{\infty}{\circ}$ \\
\hline 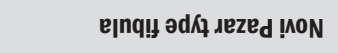 & 0 & 0 & 0 & 0 & 0 & 0 & 0 & 0 & 0 & -1 & 0 & 0 & 0 & 0 \\
\hline 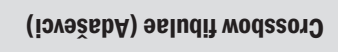 & 0 & 0 & 0 & 0 & 0 & 0 & 0 & 0 & 0 & o & 0 & o & 0 & 0 \\
\hline ерпq! реәч-ןеш!) & 0 & N & N & 0 & 0 & 0 & 0 & 0 & 0 & 0 & 0 & 0 & $\sim$ & 0 \\
\hline ગાIX еsоนдәว & -1 & + & 0 & 0 & 0 & 0 & 0 & 0 & 0 & 0 & 0 & 0 & $\rightarrow$ & 0 \\
\hline qІ еsодәэ & -1 & 0 & 0 & 0 & 0 & $\nabla$ & 0 & 0 & 0 & 0 & 0 & 0 & 0 & 0 \\
\hline$\Lambda$ еsоนәЈ & 0 & 0 & N & + & 0 & 0 & -1 & N & $\sim$ & $\circ$ & -1 & 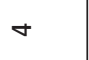 & 0 & 0 \\
\hline 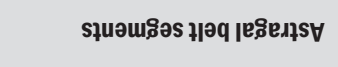 & $\vec{g}$ & 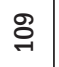 & 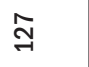 & 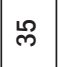 & m & $\stackrel{\infty}{=}$ & $\mathscr{n}$ & $R$ & 욤 & $\stackrel{9}{9}$ & $\Rightarrow$ & مِ & $\mathscr{q}$ & 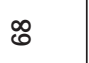 \\
\hline dep ગાəq |ešensy & -1 & -1 & N & -1 & 0 & $\sim$ & 0 & -1 & 0 & o & -1 & - & $\sim$ & 0 \\
\hline ॐ & $\frac{1}{z}$ & $\frac{\Sigma}{z}$ & $\frac{1}{z}$ & $\frac{\Sigma}{z}$ & $\frac{\Sigma}{z}$ & $\frac{\mathbb{z}}{z}$ & $\stackrel{\leftarrow}{z}$ & $\underset{z}{z}$ & $\frac{\pi}{z}$ & $\frac{\mathbb{z}}{z}$ & $\frac{\Sigma}{z}$ & $\frac{\mathbb{s}}{z}$ & $\frac{\Sigma}{z}$ & $\frac{1}{z}$ \\
\hline$\stackrel{8}{\&}$ & $\frac{\pi}{z}$ & $\frac{\pi}{z}$ & $\frac{\pi}{z}$ & 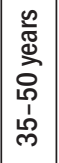 & 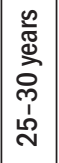 & $\overleftarrow{z}$ & $\frac{\pi}{z}$ & $\frac{\Sigma}{z}$ & $\frac{\Sigma}{z}$ & $\frac{\pi}{z}$ & $\frac{\pi}{z}$ & $\frac{\pi}{z}$ & $\frac{\pi}{z}$ & 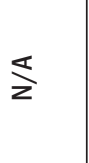 \\
\hline $\begin{array}{l}\text { 訔导 } \\
\text { 虽 }\end{array}$ & $\frac{\pi}{z}$ & $\frac{s}{z}$ & $\frac{\pi}{z}$ & -1 & -1 & $\rightarrow$ & $\frac{\pi}{z}$ & $\frac{\pi}{z}$ & $\frac{\pi}{z}$ & $\frac{\pi}{z}$ & $\frac{\pi}{z}$ & $\frac{\pi}{z}$ & $\frac{\pi}{z}$ & $\stackrel{s}{z}$ \\
\hline 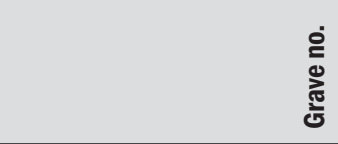 & 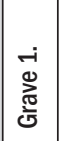 & 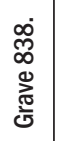 & 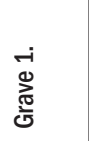 & 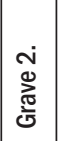 & 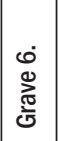 & 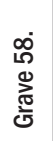 & 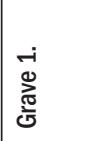 & 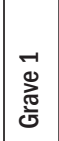 & 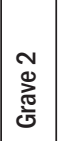 & 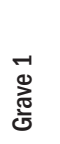 & 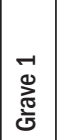 & 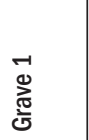 & 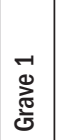 & 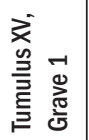 \\
\hline के & 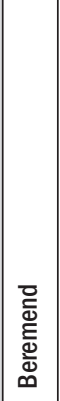 & 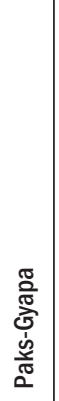 & 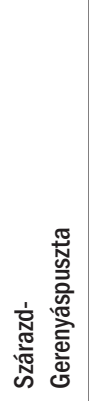 & 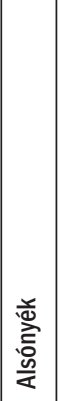 & 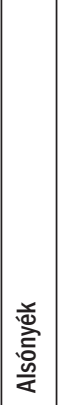 & 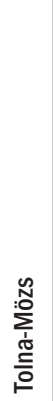 & 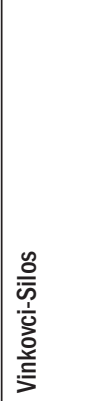 & 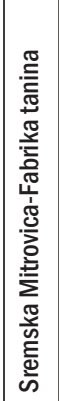 & 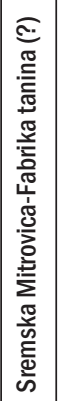 & $\begin{array}{l}\text { 言 } \\
\text { 产 }\end{array}$ & 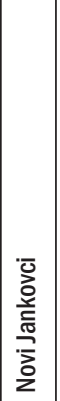 & $\begin{array}{l}\text { 형 } \\
\text { 岕 }\end{array}$ & 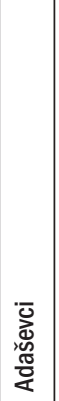 & 帝 \\
\hline Q & -1 & $\sim$ & $m$ & + & L & 0 & $r$ & $\infty$ & os & 오 & $\Rightarrow$ & ฯ & $m$ & A \\
\hline
\end{tabular}




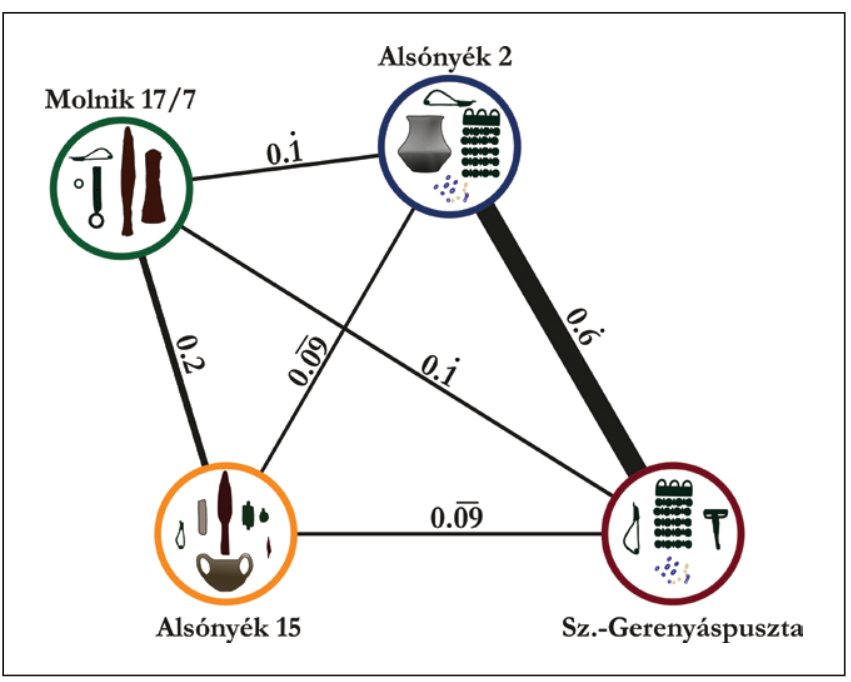

Fig. 4. Schematic similarity network among late Hallstatt burial assemblages weighted with Jaccard scores. Alsónyék 6, and 15 (Soós 2021); Szárazd-Gerenyáspuszta (MárTon 1933, 17); Molnik 17/7 (Tecco HvalA 2017, 55-56)

4. kép. Sematikus Jaccard-értékekkel súlyozott hasonlósági hálózat néhány késő Hallstatt-kori temetkezés között. Alsónyék 6, and 15 (Soós 2021); Szárazd-Gerenyáspuszta (MárTon 1933, 17); Molnik 17/7 (Tecco Hvala 2017, 55-56)

An example of the characteristic dress combination of an astragal belt, beaded necklace and Certosa fibulae in the Alsónyék cemetery is the assemblage of the Grave 2. The largest amount of metal objects in this cemetery has been found interred with this person, deceased at the age between 35 and 50. However, the largest number of grave goods is attributed to another burial, Grave 8 . The maturus / senium individual in Grave 8 was buried with a remarkable number of jewels, including three Certosa V type fibulae, six penannular rings of thin bronze wire, and amber and glass paste beads, the latter in large quantities (Fig. 6). It is worth briefly mentioning the penannular rings with a decoration imitating twisting (Fig. 6, 6-7). Similar objects were found in Transdanubia from Grave 2 in Beremend, but bent from a twisted silver wire ${ }^{66}$ and a similar jewel also came to light in one of the burials in the Szentlörinc cemetery. ${ }^{67}$ However, in large quantities, this jewellery is known south of the Drava and the Sava, especially in what is now Bosnia and Herzegovina. ${ }^{68}$

Even disregarding the small size of the sample, we face the question of whether the separation of the two groups signals social inequalities alone, i.e., whether more equipped burials belonged to the elite members of the Alsónyék community or communities. The symbols in the lower-left corner of the diagram above indicate the burials of young children in several cases, thus the number of grave goods may correlate to some extent with the age of the deceased. The position

\footnotetext{
${ }^{66}$ Jerem 1973, Abb. 7, 2-5

${ }^{67}$ Jerem 1968, Fig. 20, 9/5.

${ }^{68}$ Gavranović 2011, 217.
}

of Alsónyék Graves 4 and 11 on the diagram, with adultus/ maturus individuals, only seemingly contradicts this suggestion, because these interments were subjected to disturbance that could have led to the removal of a significant portion of the finds. The brightest example of this is Grave 11 (Fig. 7), where the entire upper body of the deceased was missing, only a glass bead and two Certosa V type fibulae remained, implying the original wealth of the burial. The graves of the adult population in Alsónyék justify Babićs and Palavestra's proposal that burials of the late Hallstatt communities in southern Pannonia are to some extent characterized by general affluence, ${ }^{69}$ except children's graves and cremation burials, but the adverse effects of disturbances need to be reiterated.

Returning to the example of Grave 2 in Alsónyék, if we look for the most easily identifiable examples of the southern Pannonian elite based on burial data, Grave 2 with the characteristic costume attests only one way that a prominent member of the community could have been identified in their burial. Graves 1 and 2 in Beremend suggest the same heterogeneity of display. Thus, merely defining the southern Pannonian elite along individuals buried with astragal belt, Certosa fibulae, and strings of beads would be an erroneous approach. $^{70}$

Nevertheless, the examples from Beremend and Sremska Mitrovica still indicate a connection between members of the newly formed elite and individuals buried in characteristic costumes. A more recent example is Grave 58 in Tolna-Mözs, containing four golden beads in addition to the usual costume elements, although these are lacking either granulation or other types of decoration, which presupposes connections with the Balkans. ${ }^{71}$ Therefore, if the network generated from the proximal point analysis of the distribution of Certosa V fibulae is thought to be somewhat suitable for depicting interactions between communities in the late $6^{\text {th }}$ century and the first half of the $5^{\text {th }}$ century BC, individuals buried with the characteristic costume can provide insight into the nature of the interactions that make up this network.

The spatial characteristics of the phenomenon of graves with the characteristic costume and their relation to the network based on the distribution of Certosa type $\mathrm{V}$ fibulae can be effectively represented by an (archaeological ${ }^{72}$ or gene$\mathrm{ral}^{73}$ ) similarity network. According to this approach, the degree of similarity found between specific attributes of archaeological contexts indicates the frequency and intensity of interactions between individuals and communities

\footnotetext{
${ }^{69}$ Babić-Palavestra 1999, 30.

${ }^{70}$ Grave 6 of the Alsónyék cemetery came to light noticeably disturbed. It appears that the burial contained an astragal belt of which only three segments remained. Similarly, a mere 13 glass paste beads of a necklace survived (Soós 2021, 56). Interestingly, as far as the area is concerned, this is the largest grave hitherto unearthed at Alsónyék.

${ }^{71}$ GAÁL 2001, 28.

${ }^{72}$ Prignano et al. 2017, 4

${ }^{73}$ ÖstboRn-Gerding 2014.
} 


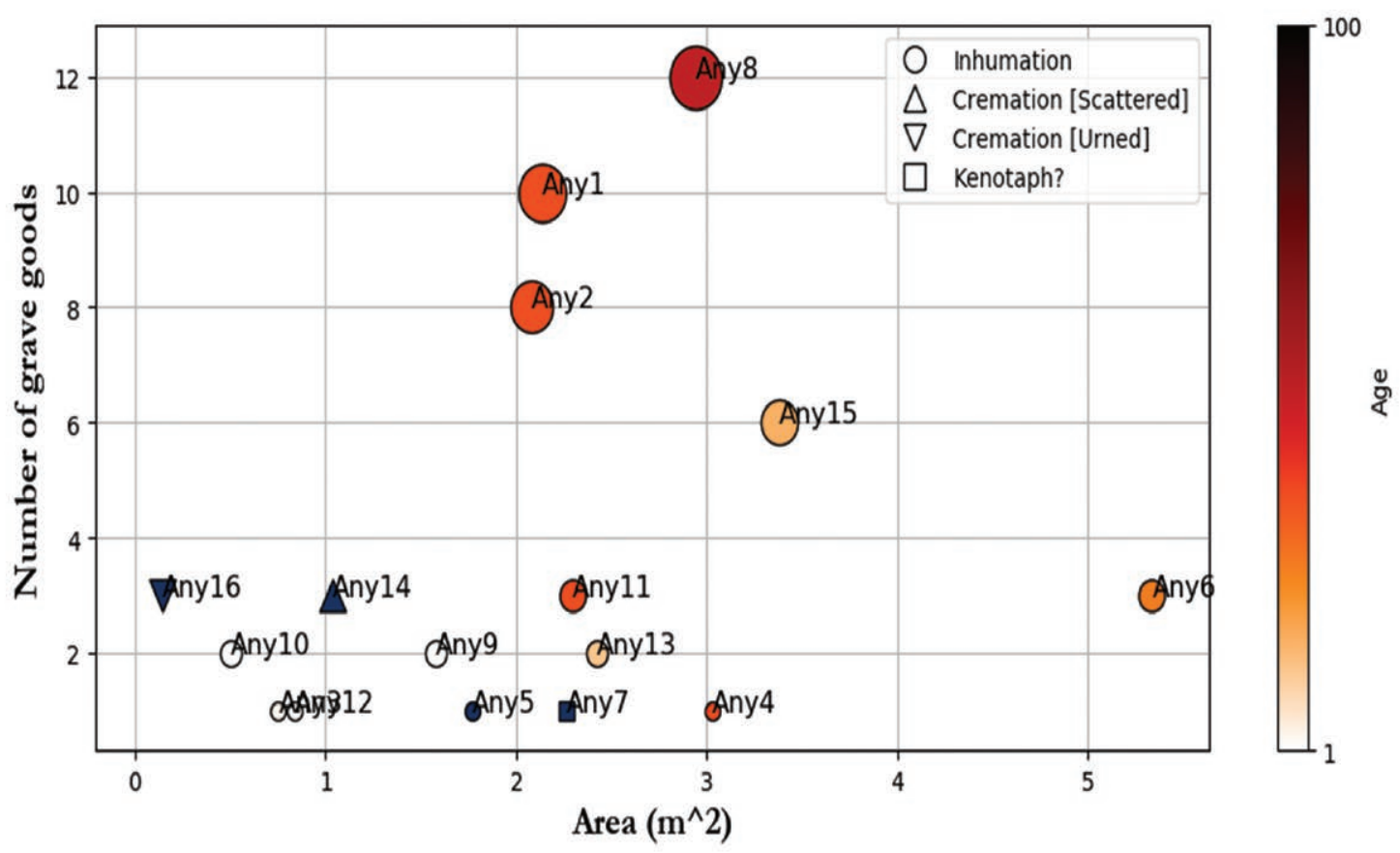

Fig. 5. Based on the data provided by T. Szeniczey and T. Hajdu (SzeniczeY-Haddu 2021)

5. kép. Szeniczey T. és Hajdu T. (2021) adatai alapján

assumed by these contexts. ${ }^{74}$ This approach provides not binary but weighted networks, i.e., instead of presence/absence of relationships between archaeological contexts, the edges (links) between them are characterized by a similarity value calculated from the finds. The higher the similarity value, the greater the probability of real interactions between the communities associated with the archaeological contexts connected by a given edge. Filtering out edges with a lower weight, i.e. similarity value, from the network reduces the number of false positive edges, but not all of these can be eliminated. Thus, in an examination of these graphs, instead of individual edges, general trends in the system should be monitored and evaluated (Fig. 4).

In recent research, archaeological similarity networks are usually based on the ceramic ${ }^{75}$ and lithic finds ${ }^{76}$ of settlement sites but there are also examples of smaller spatial units forming the nodes of the investigated networks. ${ }^{77}$

In the case of the late Hallstatt group in southern Pannonia, settlement sites provide little assistance in studying interactions between communities, as they are known only in negligible numbers and the intensity of their research varies. Thus, for the time being, we rely on the mortuary record, a source with great potential in the study of systems containing large-scale spatial connections, especially those related

\footnotetext{
${ }^{74}$ Hart 2012, 133; Mills et al. 2013, 185; ÖstborN-Gerding 2014.

${ }^{75}$ Mills et al. 2013; DE Groot 2019.

${ }^{76}$ Golitko et al. 2012; LAdEFoged et al. 2019.

${ }^{77}$ Giomi-Peeples 2019; Mazzucato 2019.
}

to the elite. ${ }^{78} \mathrm{~A}$ valuable basis for interpreting the phenomenon of burials with the characteristic dress combination is the archaeological similarity network (Fig. 8) created from assemblage data, in which similarity values calculated using the Jaccard Index presented above weigh the edges of the network.

In the figure above, only edges with a similarity value higher than 0.4 are shown, however, the density of the network, i.e. the ratio of the actual edges to the possible edges, is $44 \%$ even when using this relatively high threshold. This value indicates a remarkable homogeneity of the burials, even in cases where they are separated by a large geographical distance.

The homogeneity of the costume and the conservative and standardized design ${ }^{79}$ of its visually dominant element, ${ }^{80}$ the astragal belt (Osijek variant), suggest that this dress had a meaning that could be decoded by socially and also geographically distant communities, which contributed to the success of inter-community interactions, even in the longterm. ${ }^{81}$ If my conclusion above is correct about the strong association between the characteristic costume and the contemporary elite, then the design and use of the visual code represented by this costume was primarily related to those

\footnotetext{
${ }^{78}$ Deicke 2020.

${ }^{79}$ Filipović-Mladenović 2017, 160.

${ }^{80}$ As Table 1 suggests, astragal belts tended to comprise more than one hundred segments. As a result, their length should have commonly measured well above 1 meter.

${ }^{81}$ ARNOLD 2008, 380-381.
} 

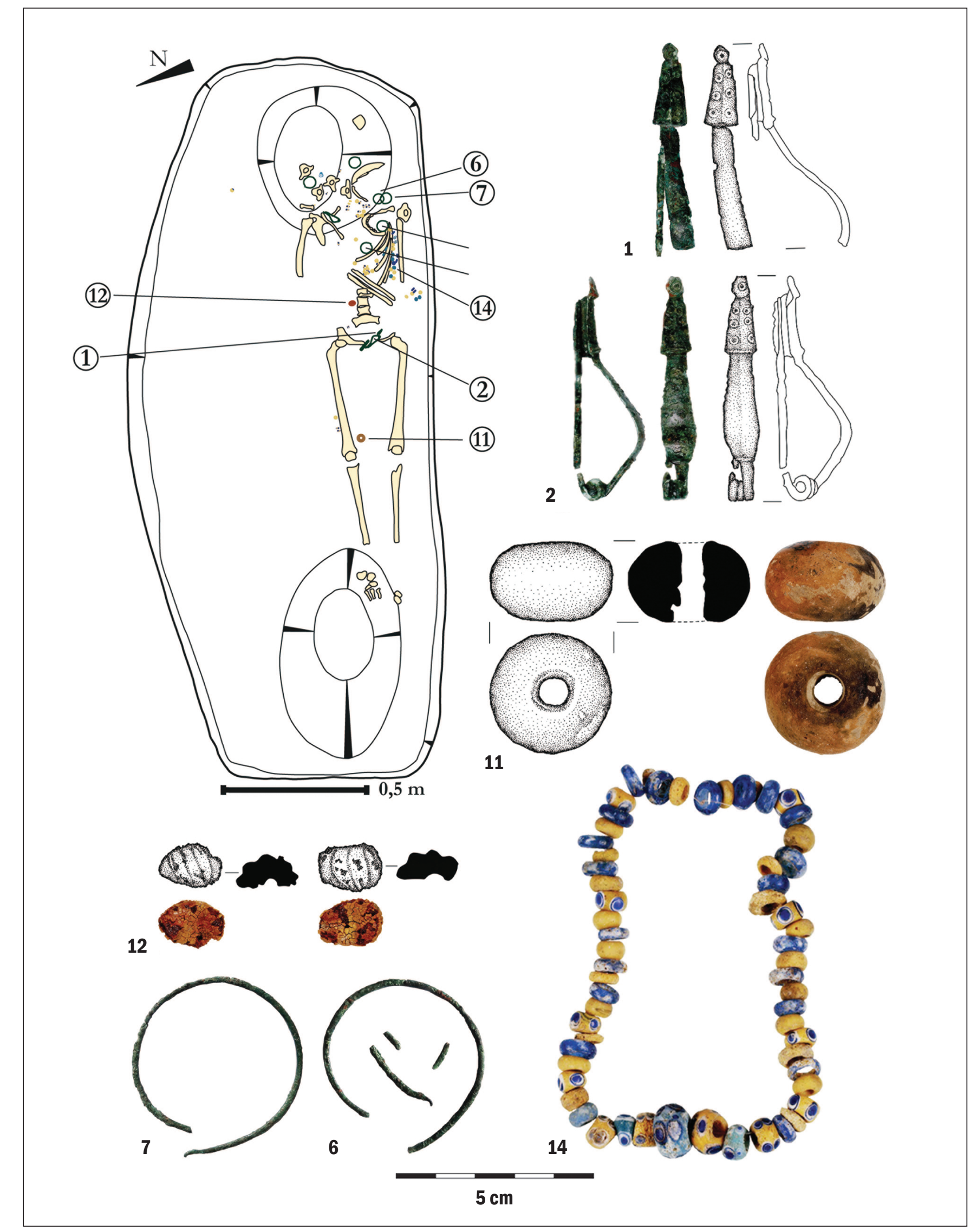

Fig. 6. Grave 8 of the Alsónyék cemetery, with selected finds associated with the burial

6. kép. Az alsónyéki temető 8 . sírja, válogatás az előkerült leletekből 


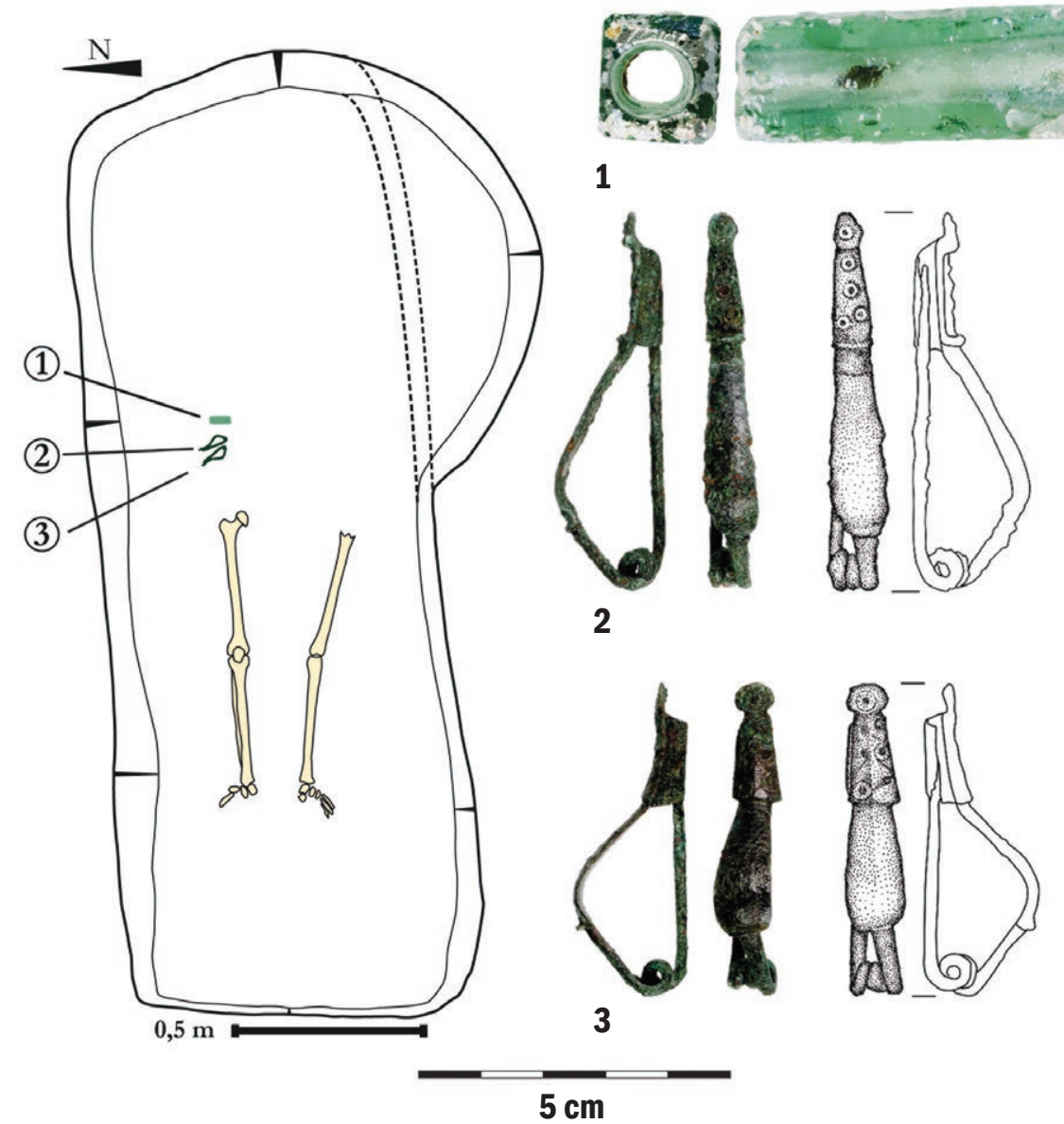

Fig. 7. Grave 11 of the Alsónyék cemetery

7. kép. Az alsónyéki temető 11. sírja

who had been explicitly interested in maintaining a relationship beyond everyday interactions and signalled their participation in the system with material signs. Given that the Szerémség region and eastern Slavonia where this characteristic "hybrid" costume probably had developed, ${ }^{82}$ we assume that the consolidating communities of southern Transdanubia increased their attempts to establish relations with the communities of these regions at the end of the 6th century BC. The individuals buried in the costume in question probably took part in this process, expressing a group identity or membership with their dress. Communities in the region between Kapos and Sava and their prominent members have been able to use this identity to signal and express their connectedness, especially on occasions of community reorganization, ${ }^{83}$ such as funerals. However, this approach is not entirely new. ${ }^{84}$

According to Marko Dizdar and Asja Tonc, astragal belts were worn primarily by adult women indicating their mar-

\footnotetext{
${ }^{82}$ Dizdar 2020, 206.

${ }^{83}$ EARLE 2018, 163.

${ }^{84}$ Majnarić-PANDŽIĆ 2009, 237.
}

ried status. ${ }^{85}$ Available physical anthropological studies are exceedingly rare, although they do not refute this proposal. Nor should my results necessarily contradict the views of these authors, insofar as marriages played an important role in regional and interregional relations, ${ }^{86}$ which is indicated in the archaeological record of the Central European Hallstatt period. ${ }^{87}$

The material of the Alsónyék cemetery in particular, but also the Beremend site, ${ }^{88}$ indicate that the graves with the characteristic dress combination were associated with relatively large, formal cemeteries, the use of which can be traced from the late $6^{\text {th }}$ to the $4^{\text {th }}$ century BC. Thus, we consider these communities to be stable groups for whom it may have been worthwhile to represent regional networks at the event of the funeral.

The similarity between Beremend-type burials applies not only to the composition of the finds but also to the ele-

\footnotetext{
${ }^{85}$ DiZDAR-TONC 2018, 57-58.

${ }^{86}$ EARLE 2018, 165.

${ }^{87}$ Teržan 1995, 100; Metzner-Nebelsick 2019, 369.

${ }^{88}$ JEREM 1973, 74.
} 


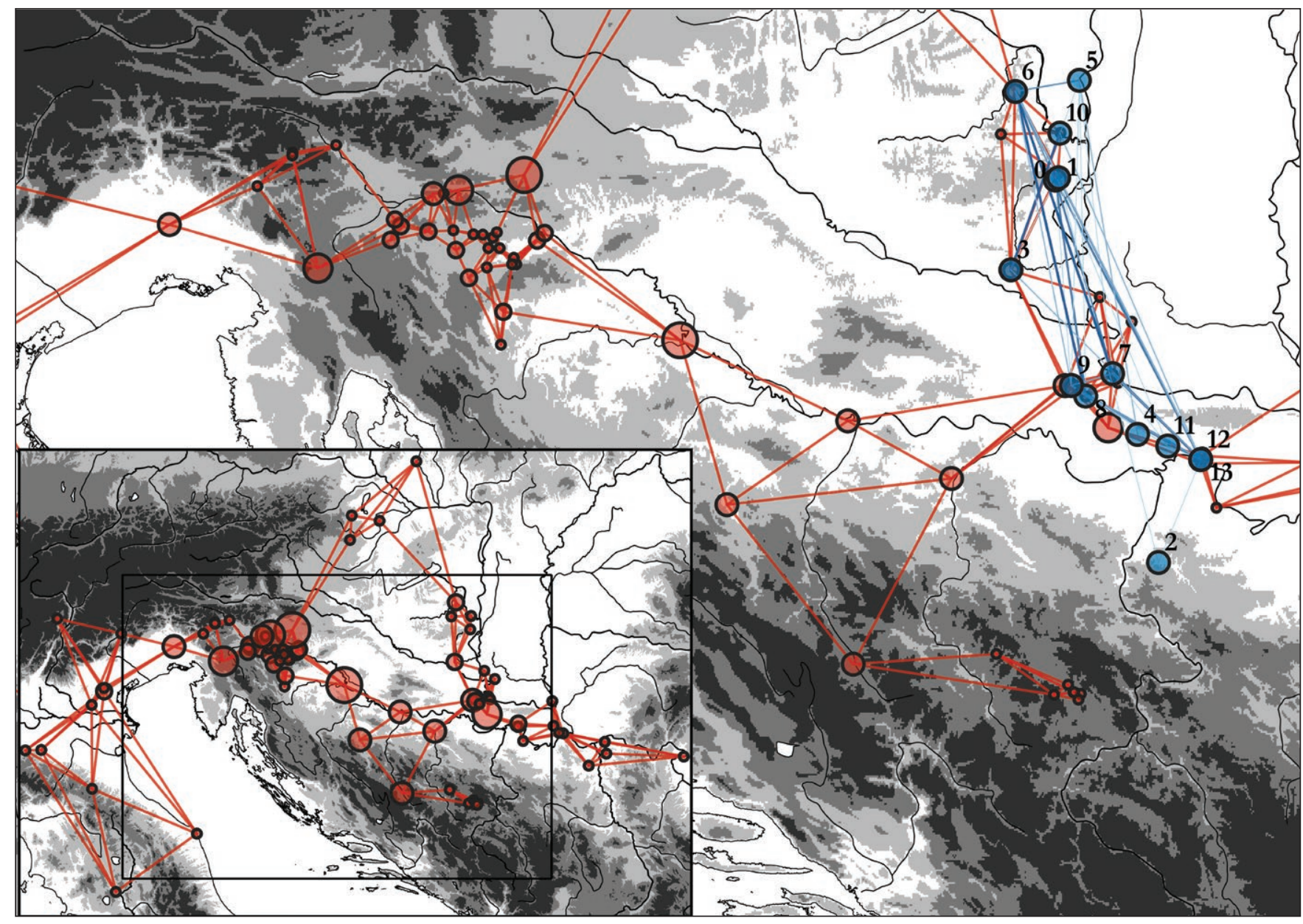

Fig. 8. Similarity network of the "Beremend-type" burials compared with the PPP network of the distribution of the Certosa 5 type fibulae. Similarity values are calculated with the Jaccard Index. The width and shade of the edges correspond to the associated weight

8. kép. A „Beremend-típusú” temetkezések hasonlósági hálózata, összevetve a Certosa V típusú fibulák elterjedése alapján létrehozott térbeli hálózattal. A hasonlósági értékeket a Jaccard-indexszel számoltam. Az élek vastagsága és színük árnyalata a hasonlósági értékkel változik

ments of the funerary rite, as well as the design and location of the graves. Especially among the find-spots with a validated location in southern Transdanubia, the burials with the characteristic costume were placed along the region's larger rivers, at the edge of their floodplains. ${ }^{89}$ The assemblages found near Sremska Mitrovica were also linked to sites near the banks of the Sava. This observation is supported by the burials of Vučedol ${ }^{90}$ and Vinkovci, ${ }^{91}$ and perhaps Kuzmin as well, which was found between Kuzmin and Bosut, 2-5 km from the present-day river Sava. ${ }^{92}$ The Adaševci burial ${ }^{93}$ and

\footnotetext{
${ }^{89}$ Soós 2020, 414-415.

${ }^{90}$ BRUNŠMid 1902, 69.

${ }^{91}$ MajNARIĆ-PANDŽIĆ 1973.

${ }^{92}$ BRUNŠmid 1902, 71.

${ }^{93}$ According to the information provided by M. Hoernes, the burial has been found between Šid and Adaševci, thus at least some $18 \mathrm{~km}$ from the present banks of the river Sava, and some $5 \mathrm{~km}$ from today's course the river Bosut (Hoernes 1901). However, the geomorphological boundary between the floodplains of the Sava and its tributary, the Bosut runs between the two modern
}

the $1^{\text {st }}$ burial of the $15^{\text {th }}$ mound in Brezjak appear to be exceptions. $^{94}$

The spatial distribution of Beremend-type burials and their similarity connections suggest that the main axis of the social interactions to which the investigated phenomenon refers is designated by the rivers and, north of the Srem region, mainly the Danube. Since human communities have also been able to use constructed markers to highlight waterways

$\triangleright$ settlements. In addition, flood events are recorded to have reached the northern environs of Adaševci (SavaGIS Geoportal, http://www.savagis.org/map\#, Access: May $1^{\text {th }} 2021$ ). In this way, the situation is quite similar to the case of the Beremend site.

${ }^{94}$ This grave is dissimilar to the Beremend-type burials due to a number of other reasons. First, it proved to be a secondary burial in a Bronze Age tumulus. Second, it contained two massive bronze bracelets and two spindle whorls, items that do not appear among the grave goods of any other Beremend-type burials. In addition, the assemblage lacks any fibulae let alone of the Certosa type (Bulatović et al. 2017, 71-73). 
that are important to them, ${ }^{95}$ the location of cemeteries probably emphasizes the importance of rivers in these cases.

Besides Beremend-type burials with the characteristic costume, their similarity network, and Certosa V fibulae, the special significance of the Danube, presumably distorting the interactions between communities towards the north, and also the lower course of the Sava can be assumed based on a broader source base, the distribution of finds related to the Osijek-variant astragal belts (Fig. 9).

Here it is worth mentioning the weak points of Marko Dizdar's and Asja Tonc's assumption regarding the significance of wearing astragal belts. The burial rite and finds of the Stubarlija cemetery excavated on the Titel plateau fit well with burials from the $5^{\text {th }}$ century $\mathrm{BC}$ in the region between the Kapos and Sava streams. ${ }^{96}$ It was the first cemetery in the region to contain graves dating back to the $5^{\text {th }}$ century BC with Certosa $\mathrm{V}$ type fibulae under documented conditions. Among the individuals buried in the five recovered graves, physical anthropological studies identified three adult women, however, their grave assemblages lacked astragal belt elements, but not other jewellery of the characteristic costume (Certosa type $\mathrm{V}$ fibulae, various glass paste beads). ${ }^{97}$ In addition, the Stubarlija cemetery is closely linked to the burial sites in eastern Slavonia and southern Transdanubia by the burial rite and other types of grave goods (such as the so-called kantharoi and cowrie shells). Consequently, it is reasonable to assume that in some respects they are part of the same system, which can be called either the Srem group ${ }^{98}$ or, rather, the late Hallstatt group in southern Pannonia. ${ }^{99}$ However, only a very small part of this system of parallel, overlapping and subordinate networks is currently detected (Fig. 10).

\section{SPHERES OF INTERACTION IN LATE HALLSTATT-PERIOD SOUTHERN PANNONIA}

However, based on the available information, it can be assumed that the interaction and integration of the southern Transdanubian communities and their prominent members have been unequally influenced by the rivers in the late $6^{\text {th }}$ and early $5^{\text {th }}$ centuries BC, because waterways allow for fast traffic and transportation. ${ }^{100}$ An important recognition in this respect is that the amount of bronze placed in the graves of different cemeteries in the eastern half of the Bronze Age Carpathian Basin correlates with how important or central a given cemetery had been located in the Tisza drainage sys-

\footnotetext{
${ }^{95}$ O’SHEA 2011, 162.

${ }^{96}$ Medović 2007; Dizdar 2015, 53.

${ }^{97}$ Medović 2007.

${ }^{98}$ ГАРАПАНИН 1973, 514; VASIĆ 1987, 557-558; VASIĆ 1989.

${ }^{99}$ Guštin-Teržan 1977, 80; TeržAn 1977b, 20; Dizdar 2010, 299; Kemenczei 2012, Abb. 2; PotrebicA-Dizdar 2014b, 135; DiZDAR 2015.

${ }^{100}$ O'SHEA 2011, 162.
}

tem. Thus, different locations offered different opportunities for the communities to access bronze raw materials through the waterways. ${ }^{101}$ For the communities in southern Transdanubia at the end of the $6^{\text {th }}$ and the beginning of the $5^{\text {th }}$ century $\mathrm{BC}$, the proximity of the Danube may have been a distorting factor to the advantage of the communities in southern Transdanubia seeking contacts with the elite consolidating in the area between Beremend and Sremska Mitrovica.

Beremend deserves special attention in this case, where a close but difficult-to-determine relationship between the two excavated graves is assumed. The interpretation of the two burials points to different directions regarding the social networks of the region. Grave 1 yielded the characteristic costume (Fig. 1, B), which, according to my proposal, is a visual repertoire that fits into a regional system of relations between the communities that inhabited the area between the rivers Kapos and Sava. The presence of the costume can signal the integration of the Beremend community into that network, perhaps through the individual buried in Grave 1. This possibility is primarily reflected in the more spectacular elements of the costume. At the same time, the silver bead among the details that are difficult for socially distant observers to discern identifies the deceased as a member of a broader system.

The spectacular elements of the costume in Grave 2 can also be interpreted along the latter aspect (Fig. 1, A). Instead of an astragal belt, the deceased wore a composite belt of openwork plates and bronze spirals, presumably one of the latest pieces of its type. ${ }^{102}$ These belts spread mainly in the area between the rivers Velika Morava and Isker, ${ }^{103}$ but the nearest parallel of the specimen found in the Beremend burial is known from Donja Dolina. ${ }^{104}$ Another highlight of the tomb is a bent bronze plate wand or sceptre, a type primarily known from the elite graves of the Dolenjska group in Slovenia. ${ }^{105}$ In addition to these artefacts, Novi Pazar-type fibulae and twisted silver penannular rings also appear as part of the funerary attire. This distinctly unique, non-canonized composition indicates a system of relationships broader than the phenomenon indicated by the distribution of the graves with the characteristic costume. This funerary costume as a social diacritic, displaying seemingly archaic (composite belt) and specifically new elements (Certosa type $\mathrm{V}$ fibula) ${ }^{106}$ and both precious metal and bronze objects, is presumably intended to support uniqueness and social distinction. ${ }^{107}$ Thus, in the similarity network created based on burials

\footnotetext{
${ }^{101}$ DufFy 2020.

${ }^{102}$ DizDAR 2020, 197.

${ }^{103}$ VASIĆ $1971,1$.

${ }^{104}$ Truhelka 1904, Taf. 40.

${ }^{105}$ Schumann 2015, 228; Tecco Hvala 2012, 341.

${ }^{106}$ Currently, Grave 2 is dated to the late $6^{\text {th }}$ and early $5^{\text {th }}$ centuries BC (TeržAn 1990, 159; Metzner-Nebelsick 2002, 418; PotreBICA-DIZDAR 2014a), hence it is supposed to be among the earliest appearances of Certosa fibulae in the southern Pannonian region.

${ }^{107}$ SCHORTMAN-URBAN 1987, 71.
} 


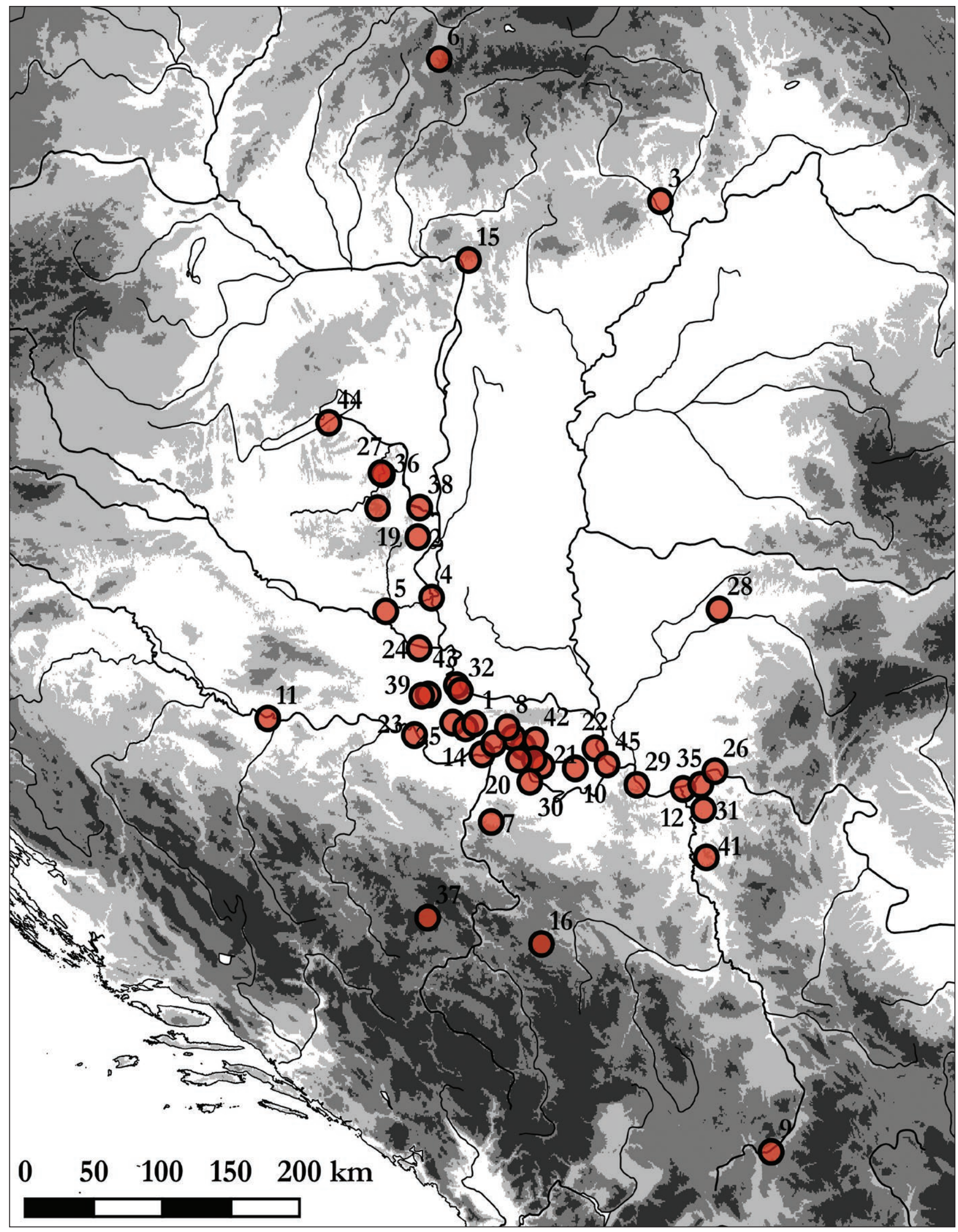

Fig. 9. The distribution of specimens of the Osijek variant of the astragal belts (after Filipović-MLAdenović 2017, with supplements)

9. Kép. Az Osijek-variánshoz köthető asztragalosz övek elterjedése (FILIPović-MLadenović 2017 alapján, kiegészítésekkel) 


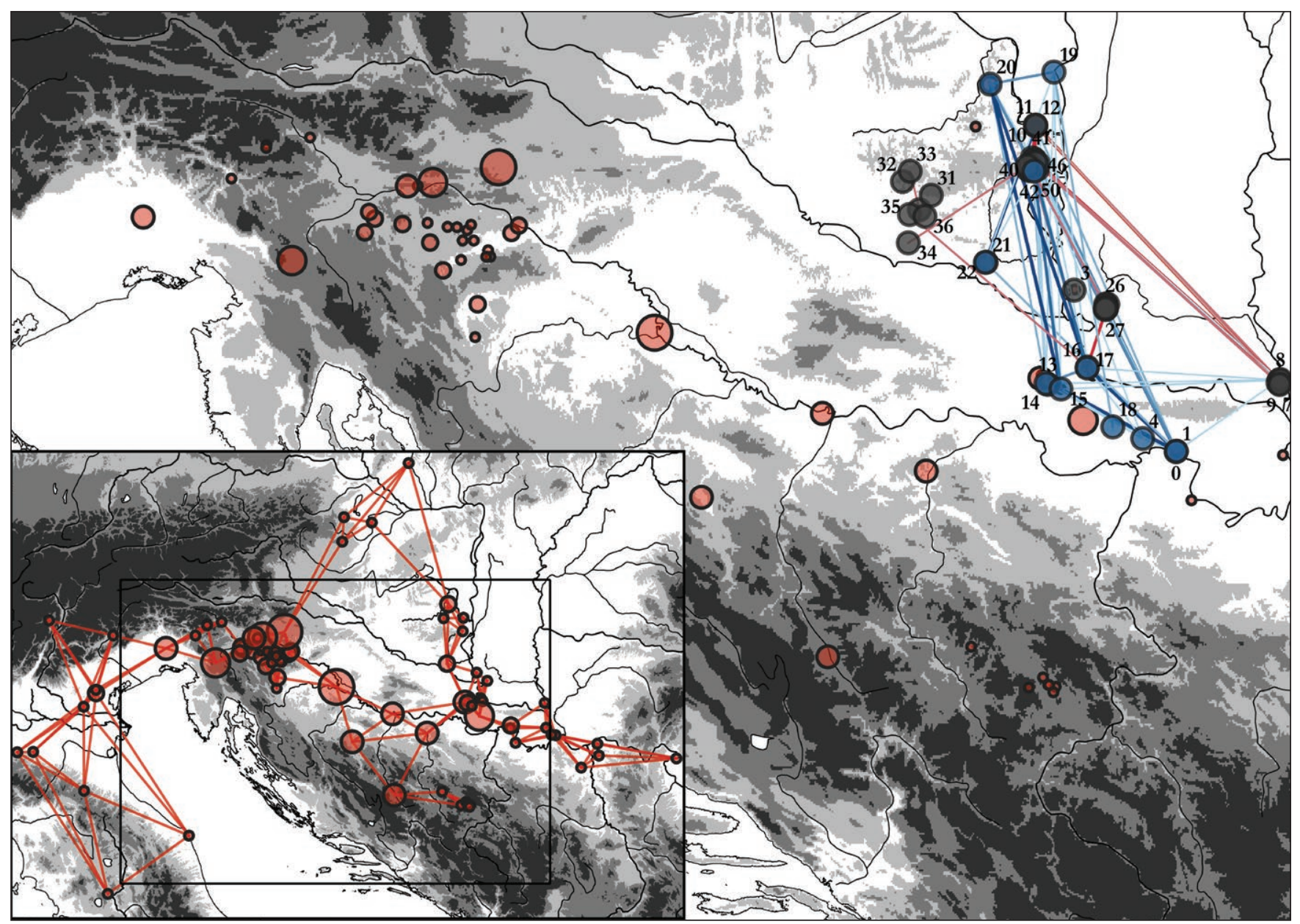

Fig. 10. Similarity network of the burials of the southern Pannonian late Hallstatt group. Blue points represent the "Beremend-type" burials. Blue edges are associated with "Beremend-type" burials, red edges are not. Similarity values are calculated with the Jaccard Index. The width and shade of the edges correspond to the associated weight. (Applied threshold $=0.4$ )

10. kép. A dél-pannoniai késő Hallstatt-csoport temetkezései alapján létrehozott hasonlósági hálózat. A kék pontok a „Beremend-típusú” temetkezéseket jelenítik meg. A kék élek „Beremend-típusú” temetkezésekhez kapcsolódnak, a pirosak nem. A hasonlósági értékeket a Jaccard-indexszel számoltam. Az élek vastagsága és színük árnyalata a hasonlósági értékkel változik. (Alkalmazott küszöbérték = 0,4)

containing Certosa type V fibulae (threshold $=0.4)$, the marker of Beremend Grave 2 remains without edges (Fig. 11). ${ }^{108}$

This burial helps to capture the extent to which the elites of southern Pannonia were integrated into a Prestige Good Network ${ }^{109}$ in the late $6^{\text {th }}$ and early $5^{\text {th }}$ centuries BC. A similar assumption is supported by the stray finds from the vicinity of Sremska Mitrovica. Based on the evidence, it can also be recognized that the dominant organizing axes of the relationship system based on the exchange of prestige objects have been the river Sava as a pivotal channel of communication in the era, and other north-south-oriented river valleys of the Balkans. ${ }^{110}$

${ }^{108}$ The grave begins to have linkages when the treshold value is lowered, naturally, because all vertices have at least one common attribute, i.e., the Certosa fibulae of Type 5.

${ }^{109}$ Chase-DunN-Hall 1997, 52.

${ }^{110}$ Potrebica 2008.
However, based on the graves examined, astragal belts, Certosa fibulae, and necklaces made of glass and amber beads appear to be elements of a canonized costume, implying that the Danube had been an important axis of a system based on more intense and presumably more frequent interactions in the period under discussion. ${ }^{111}$ The appearance of this costume from the lower reaches of the Sava up to the line of the Kapos stream indicates the development of a visually easily identifiable (well-noticeable) stylistic similarity in the clothing of certain members of the communities, which, due to its high visibility, underlines the importance of inter-community interaction, and implies the existence of

${ }^{111}$ References to a similar phenomenon in the literature can be found in connection with the Late Bronze Age and the early Hallstatt period, due to the similarities in the find material of the sites in the area between Dunaföldvár and Dalj (PATEK 1968, 24; LožNJAK DizDar 2015, 38). 


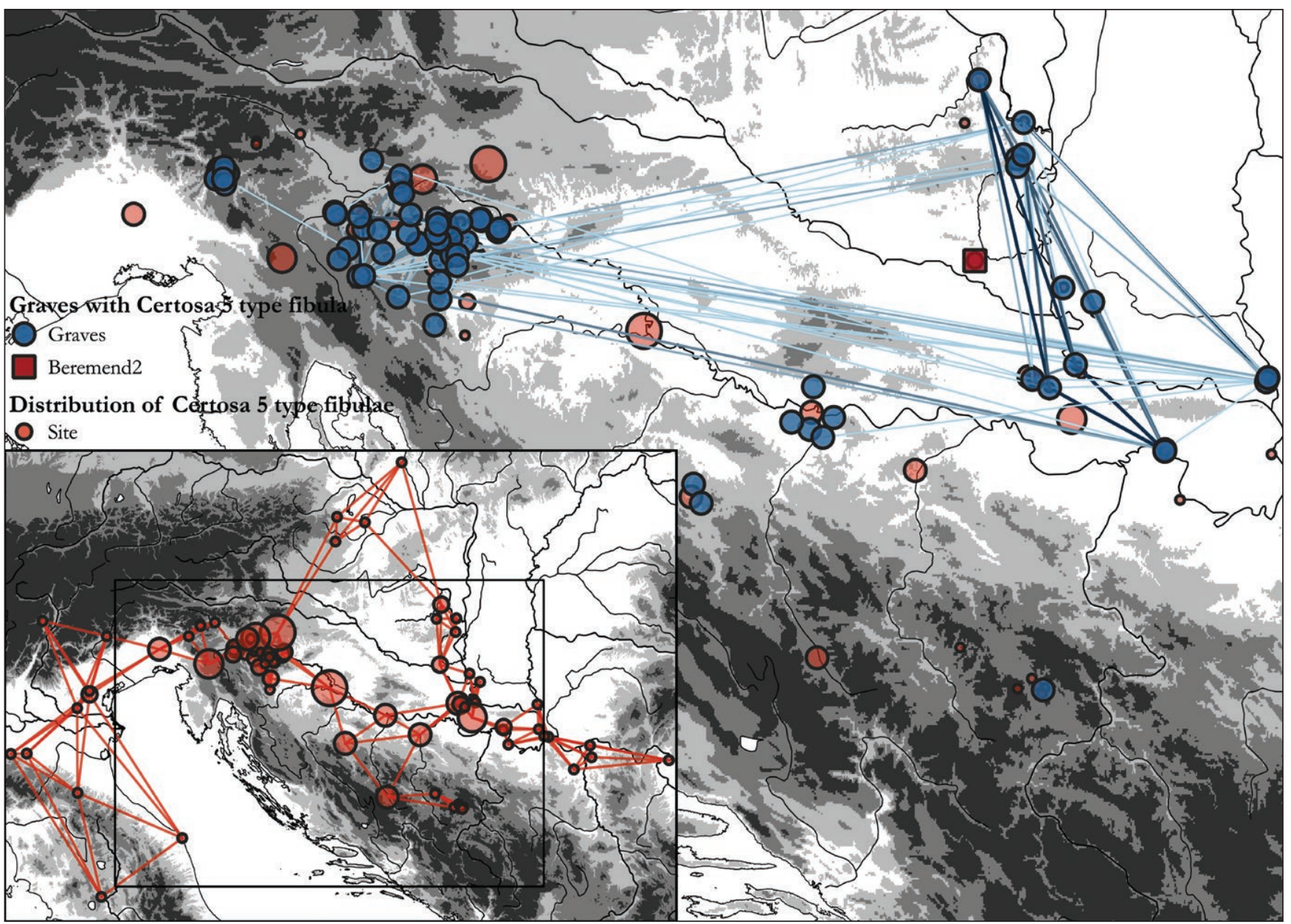

Fig. 11. Similarity network of the burials containing Certosa 5 type brooches. Similarity values are calculated with the Jaccard Index. The width and shade of the edges correspond to the associated weight. For the sake of better visibility of the structural properties of the network, burials from the same sites are displayed with some offset from their exact geographic location. (Applied threshold $=0.4$ )

11. kép. A Certosa V típusú fibulát tartalmazó temetkezések hasonlósági hálózata. A hasonlósági értékeket a Jaccard-indexszel számoltam. Az élek vastagsága és színük árnyalata a hasonlósági értékkel változik. A hálózat szerkezetének jobb átláthatósága érdekében, az egy lelőhelyről származó temetkezések a valós földrajzi elhelyezkedésüktől kis eltéréssel kerültek ábrázolásra. (Alkalmazott küszöbérték =0,4)

regional social identity. ${ }^{12}$ Although there are currently relatively few find types associated with this phenomenon, the limits of its distribution can be seen. As an example, both Certosa fibulae and bronze pegs belonging to astragal belts have been found during the excavations of the Donja Dolina cemetery in the early $20^{\text {th }}$ century, but not together, in the same grave assemblages. The discussed phenomenon can be identified according to the model of Ch. Chase-Dunn and T . Hall as an archaeological residue of a Political / Military Network, ${ }^{113}$ which is of smaller scale than the aforementioned Prestige Goods Network, restricted mainly to the area along the Danube, bordered by the Kapos and Sava from the North and South, respectively.

\section{CONCLUSIONS}

The archaeological record of the $6^{\text {th }}-5^{\text {th }}$ centuries BC in southern Transdanubia, eastern Slavonia and the Szeremség regions is limited and mostly originates in excavations from the late $19^{\text {th }}$ and early $20^{\text {th }}$ centuries. Therefore, the applicability of network models used in this paper is also restricted. With the currently available find material, the network approach can be used to represent the spatial relationships of certain multidimensional phenomena of the finds ${ }^{114}$ rather than to analyze the phenomena. The most important obstacle is the small number of excavated settlements, especially in southern Transdanubia. For the time being, settlement material

\footnotetext{
${ }^{112}$ CARr 1995, 189-191; PARKINSON 2006, 36-38.

${ }^{113}$ Chase-DunN-Hall 1997, 52-53.
}

${ }^{114}$ Östborn-Gerding 2014. 
from the site Szajk cannot be compared with other settlement remains in this region. Thus, among other things, the question has yet to be answered whether the communities along the Danube were more likely to be integrated into the system of relationships gravitating towards the Szerémség region, as the burial record suggests. Possibly, the question itself is flawed, as the identities represented in the mortuary context may have been different from those that were relevant in the interactions within and between the settlements.

The finds of the Szajk settlement, about $10 \mathrm{~km}$ from the present-day Danube riverbed, especially the oinochoe-type jugs found there, suggest that the community had connections to the South beyond the Drava-Sava area in the late $6^{\text {th }}$ and early $5^{\text {th }}$ centuries $\mathrm{BC}$, similar to the situation assumed by the finds from the Beremend burials. ${ }^{115}$

The two burials discovered on the outskirts of Beremend in the early 1960s yielded material from the same period. ${ }^{116}$ The graves were found close to each other, presumably well separated from the rest of the cemetery, ${ }^{117}$ which suggest a close association between the two buried individuals. However, the grave goods still show significant differences, which, in a broader sense, leads to the recognition of two systems of relations among the consolidating communities of southern Pannonia, based on different mechanisms and interactions.

The astragal belt, various types of Certosa fibulae, glass paste and amber beads found in Grave 1 form a characteristic dress combination, which is well documented along the right bank of the Danube, from the Kapos stream in the North down to the lower Sava in the South. The similar appearance of this costume and its visually dominant element, the astragal belt throughout this relatively large area is striking. Based on the information exchange theory, this costume probably did not play an important role in interactions within a community, but in establishing and maintaining contact between socially distant participants. As burials with such costumes have been unearthed in close connection with the larger rivers of the southern Pannonian region, there is a possibility that proximity to waterways and especially the Danube in the north may have affected the ability of communities to integrate into this system differently.

In contrast, the attire from Grave 2 which blends highprestige objects of archaic appearance and also specifically new, renders the Beremend community in a more encompassing but looser network of connections. One of the major organizing axes of this system may have been the river Sava, as seems to be emphasized by the spread of different Certosa types and the outstanding importance of the settlement and cemetery of Donja Dolina. ${ }^{118}$

Conversely to the network connecting the communities in the area between the Kapos and the Sava, the distribution of high and medium prestige objects is well attested in the latter system, but these objects appear in different social contexts from region to region. Due to the scarcity of settle-

\footnotetext{
${ }^{115}$ GÁвOR 2009; GÁti 2014, 118-119.

${ }^{116}$ JEREM 1973.

${ }^{117}$ JEREM 1973, 72.

${ }^{118}$ Potrebica 2008, 196; Blečić Kavur-JAŠARević 2016, 226.
}

ment finds, these contexts can be identified mainly in the similarities and differences in the burial record, the composition of funerary costumes and grave goods. In the regions of eastern Slavonia and the Szerémség, these objects fit into a new concept, a "new, hybrid costume."119 Remarkably, however, this concept was able to spread successfully without reinterpretations in the approximately $200 \mathrm{~km}$ long strip of land between the Kapos and Sava streams at the end of the $6^{\text {th }}$ and the first half of the $5^{\text {th }}$ century BC, indicating a system of relations based on intensive interactions. The rivers, especially the Danube, which the contemporary communities highlighted by the location of their cemeteries and making them part of their social landscape, certainly played an important role in this system.

\section{ACKNOWLEDGEMENTS}

This research was supported by the UNKP-18-2 New National Excellence Program of the Ministry of Human Capacities. Translated by Attila Király and Bence Soós.

\section{BIBLIOGRAPHY}

Amati, Viviana-Shafie, Termeh-Brandes, Ulrik

2018 Reconstructing Archaeological Networks with Structural Holes. Journal of Archaeological Method and Theory 25, 226253, DOI: https://doi.org/10.1007/s10816-017-9335-1

Arnold, Bettina

2008 Gender and Archaeological Mortuary Analysis. In: Nelson Milledge, S. (ed.): Handbook of Gender in Archaeology. Berkeley, 137-170.

BAbić, StašA-Palavestra, Aleksandar

1999 Northern Serbia in the Second Half of the First Millenium BC - Socio-economic Aspects. In: Vasić, M. (ed.): Le Djerdap/Les Portes de Fer a la Deuxieme Moitie du Premiern Millenaire av. J. Ch. Jusqu'aux Guerres Daciques. Kolloquium in KladovoDrobeta-Turnu Severin (September-October 1998). Beograd, 28-33.

Bencs JÁnos-DÁvid FerenC

2016 „Merre a Dráva vize öntözi Pannoniát”. Drávaszabolcs nyolc évszázada. Drávaszabolcs.

BLEČIĆ, MARTINA

2007 Status, symbols, sacrifices, offerings. The diverse meanings of Illyrian helmets. Vjesnik Arheološkog muzeja u Zagrebu 40, 73-116.

Blečić Kavur, MaRTina

2017 Ilirske kacige iz Crne Gore (Illyrian helmets from Montenegro). Nova antička Duklja 8, 31-57.

Blečić Kavur, Martina-Mličević-CAPEK, IVANKA

2012 O horizontu ratničkih grobova 5. stoljeća pr. Kr. na prostoru istočne obale Jadrana i njezina zaleđa: primjer novog nalaza iz Vranjeva Sela kod Neuma (On the horizon of warrior graves from 5th century BC on the territory of the eastern Adriatic coast and its hinterland: the case of a new discovery in Vranjevo Selo near Neum). Prilozi Instituta za arheologiju u Zagrebu 28, 31-94.

${ }^{119}$ DiZDAR 2020, 205-206. 
Blečić Kavur, Martina-Pravidur, Andrijana

2012 Ilirske kacige s područja Bosne i Hercegovine (Illyrian helmets from Bosnia and Herzegovina). Glasnik Zemaljskog muzeja Bosne i Herzegovine u Sarajevu - Arheologija 53, 35-136.

Blečić Kavur, Martina-Jašarević, Aleksandar

2016 The Known Unknown: New Archaeological „Clothes” of Ritešić. In: Sîrbu, V.-Jevtić, M.-Dmitrović, K.-Ljuština, M. (eds): Funerary Practices of the Bronze and Iron Ages in Central and South-Eastern Europe. Proceedings of the $14^{\text {th }}$ International Colloquium of Funerary Archaeology in Čačak, Serbia, $24^{\text {th }}$ $27^{\text {th }}$ September 2015. Belgrad-Čačak, 225-236.

BRUNŠMID, JOSIP

1902 Prethistorijski predmeti iz Srijemske Županije (Prehistoric objects from Srem County). Vjesnik Arheološkog muzeja u Zagrebu 6:1, 68-86.

Bulatović, Aleksandar-Filipović, Vojislav-Gligorić, RadA

2017 Лозница. Културна стратиграфија праисторијских локалитета у Јадру, Рађевини и Азбуковици (Loznica. Cultural Stratigraphy of the Prehistoric Sites in Jadar, Rađevina and Azbukovica). Belgrade-Loznica.

CARr, Christopher

1995 A Unified Middle-Range Theory of Artifact Design. In: Carr, Ch.Neitzel, Jill E. (eds): Style, Society, and Person. Archaeological and Ethnological Perspectives. New York, 171-258.

Chase-Dunn, Christopher-Hall, Thomas D.

Rise and Demise: Comparing World-Systems. Boulder, CO.

Deicke, Aline J. E.

2020 Entangled identities. Processes of status construction in late Urnfield burials. In: Donnellan, L. (ed.): Archaeological networks and social interaction. London, 38-63.

DizDAR, MARKo

2010 Kantharoi of Autochthonous - "Pannonian" Origin from the La Tene Culture Cemetery in Zvonimirovo, Croatia. In: Berecki, S. (ed.): Iron Age Communities in the Carpathian Basin. Proceedings of the International Colloquium from Târgu Mureş 9-11 October 2009. Bibliotheca Mvsei Marisiensis - Seria Archaeologica 2. Târgu Mureş, 297-307.

2015 Late Hallstatt Female Grave from Belišće. A Group of Late Hallstatt Finds in the Lower Drava Valley. In: Gutjahr, Ch.Tiefengraber, G. (Hrsg.): Beiträge zur Hallstattzeit am Rande der Südostalpen. Akten des 2. Wildoner Fachgespräches am 10. und 11. Juni 2010 in Wildon/Stmk. Internationale Archäologie - Arbeitsgemeinschaft, Tagung, Symposium, Kongress 19. Rahden/Westf., 45-60.

2019 New Late Hallstatt Finds from the Vinkovci Region (Eastern Croatia): A Contribution to the Study of Impacts from the Balkans to the southeastern Carpathian Basin. In: Filipović, V.Bulatović, A.-Kapuran, A. (eds): Зборник радова у част 80 г. живота Растка Васића (Papers in Honour of Rastko Vasić $80^{\text {th }}$ Birthday). Belgrade, 319-344.

2020 The Late Hallstatt Connections between the Southeastern Carpathian Basin and the Western and Central Balkans: The Beautiful Ladies from the South. In: Gavranović, M.Heilmann, D.-Kapuran, A.-Verčík, M. (eds): Spheres of Interaction. Contacts and Relationships between the Balkans and Adjacent Regions in the Late Bronze / Iron Age $\left(1^{\text {th }}-5^{\text {th }}\right.$ Centuries $\mathrm{BCE}$ ). Proceedings of the Conference held at the Insitute of Archaeology, Belgrade 15-17 September, 2017. Perspectives on Balkan Archaeology 1. Rahden/Westf., 189-216.

DizDAR, MARKo-Tonc, AsJa

2018 Not just a belt: Astragal belts as part of Late Iron Age female costume in the south-eastern Carpathian basin. Starinar 68, 47-63. DOI: https://doi.org/10.2298/STA1868047D
DufFy, PAUL R

2020 River networks and funerary metal in the Bronze Age of the Carpathian Basin. PLoS ONE 15(9): e0238526. DOI: https:// doi.org/10.1371/journal.pone.0238526

Dmitrović, Katarina-Ljustina, Marija

2020 The Abundance Revealing Status? First Iron Age Princely Necropolises in Western Serbia and Their Relation to The Common Funerary Practice. In: Matei, S. (ed.): Mousaios XXIII. Bronze and Iron Ages in Eurasia: Rituals and Grave Good as Possible Markers of the Social Identity of the Dead. Proceedings of the 18th International Colloquium of Funerary Archaeology, Buzău (Romania), 17th-20th of October 2019. Buzău, 103-114.

Dular, Janez - Tecco Hvala, Sneža

2007 South-Eastern Slovenia in the Early Iron Age. Opera Instituti Archaeologici Sloveniae 12. Ljubljana.

EARLE, Timothy

2018 Bronze Age Economics: The First Political Economies. New York.

Eibner, Alexandrine

2001 Der Donau-Drau-Save-Raum im Spiegel gegenseitiger Einflußnahme und Kommunikation in der frühen Eisenzeit. In: Lippert, A. (Hrsg.): Die Drau-, Mur- und Raab-Region im 1. vorchristlichen Jahrtausend. Akten des Internationalen und Interdisziplinären Symposiums vom 26. bis 29. April 2000 in Bad Radkersburg. Universitätsforschungen zur prähistorischen Archäologie 78. Bonn, 181-190.

EGg, MARKus

2010 Zentralisierungsprozesse und Siedlungsdynamik im Südostalpengebiet (9-6. Jh. v. Chr.). In: Krausse, D. (Hrsg.): „Fürstensitze" und Zentralorte der frühen Kelten. Abschlusskolloquium des DFG-Schwerpunktprogramms 1171 in Stuttgart, 12.-15. Oktober 2009. Teil 2. Forschungen und Berichte zur Vor- und Frühgeschichte in Baden-Württemberg 120/2. Stuttgart, 61-78.

2013 Zum „Untergang” der Osthallstattkultur. In: Egg, M.-Kramer, D. (Hrsg.): Die hallstattzeitlichen Fürstengräber von Kleinklein in der Steiermark: der Kröllkogel. Monographien RGZM 110. Mainz, 473-483.

Estrada, Ernesto-Knight, Philip

2015 A First Course in Network Theory. Oxford.

Filipović, Vojislav M.-Mladenović, Ognjen

2017 Prilog proučavanju članaka astragalnih pojaseva sa teritorije centralne i jugoistočne Evrope (Contribution to the Study of Astragal Belt Segments from the Territory of Central and Southeastern Europe). Prilozi Instituta $\mathrm{za}$ arheologiju $\mathrm{u}$ Zagrebu 34, 143-184.

Filipović, Vojislav M.-VAsić, Rastko

2017 Illicit Antiquities Plague in Serbia. Glasnik - Journal of Serbian Archaeological Society 33, 335-348.

GaÁl, Attilla

2001 Késő vaskori sír az S-9-es út területéről (Späteisenzeitliches Grab vom Gebiet der Autostraße S9). In: Gaál, A. (szerk.): Tolna megye évszázadai a régészet tükrében. Szekszárd, 27-30.

ГАРАшАнин, Милчтин

1973 Праисторија на тлу Сп. Србије. Београд.

Gavranović, Mario

2011 Die Spätbronze- und Früheisenzeit in Bosnien. Teil 1. Universitätsforschungen zur prähistorischen Archäologie 195. Bonn.

GÁBOr Olivér

2009 Oinochoe jugs from the 5th century BC found in Szajk (Baranya County). In: Bíró, Sz. (szerk.): Ex Officina... Studia in honorem Gábler Dénes. Győr, 135-146. 
GÁL Krisztián-MolnáR AtTila

2004 Sé-Doberdó. Az 1998-as és 2001-es ásatások vaskori leletenyaga. Savaria 28, 159-230.

Gáti, Csilla

2009 A szajki (Baranya megye) koravaskori telep kulturális kapcsolatai (Cultural contacts of the Early Iron Age settlement at Szajk, Baranya County). In: Ilon, G. (szerk.): $\mathrm{M} \Omega \mathrm{MO} \Sigma$ VI. Öskoros Kutatók VI. Összejövetelének konferenciakötete Nyersanyagok és kereskedelem, Kőszeg, 2009. március 19-21. Szombathely, 65-77.

2014 On the Crossroads of Cultures. Cultural and Trade Connections of the Site of Szajk in South Transdanubia in the sixthfourth Centuries BC. In: Berecki, S. (ed.): Iron Age crafts and craftsmen in the Carpathian Basin. Proceedings of the international colloquium from Târgu Mureş 10-13 October 2013. Bibliotheca Mvsei Marisiensis - Seria Archaeologica 7. Târgu Mureş, 115-138.

Giomi, Evan-Peeples, Matthew A.

2019 Network analysis of intrasite material networks and ritual practice at Pueblo Bonito. Journal of Anthropological Archaeology 53, 21-33. DOI: https://doi.org/10.1016/j. jaa.2018.10.002

Golitko, Mark-Meierhoff, James-Feinman, Gary M.-Williams, PATRICK RYAN

2012 Complexities of collapse: the evidence of Maya obsidian as revealed by social network graphical analysis. Antiquity 86 507-523. DOI: https://doi.org/10.1017/S0003598X00062906

De Groot, Beatrijs G.

2019 A Diachronic Study of Networks of Ceramic Assemblage Similarity in Neolithic Western Anatolia, the Aegean and the Balkans (c. 6600-5500 BC). Archaeometry 61:3, 600-613. DOI: https://doi.org/10.1111/arcm.12450

Guštin, Mitja-TeržAn, BibA

1977 Beiträge $\mathrm{zu}$ den vorgeschichtlichen Beziehungen zwischen dem Südostalpengebiet, dem nordwestlichen Balkan und sem südlichen Pannonien im 5. Jahrhundert. In: Markotic, V. (ed.): Ancient Europe and the Mediterranean: Studies presented in honour of Hugh Hencken. Warminster, 77-89.

HART, JOHN P.

2012 The effects of geographical distances on pottery assemblage similarities: a case study from Northern Iroquoia. Journal of Archaeological Science 30, 128-134. DOI: https://doi.org/ 10.1016/j.jas.2011.09.010

Hoernes, Moritz

1901 Funde verschiedener Altersstufen aus dem westlichen Syrmien Mitteilungen der Prähistorischen Kommission 1:5. Wien, 265289.

Jereb, Mojca

2016 Die Bronzegefäße in Slowenien. Prähistorische Bronzefunde II/19. Stuttgart.

\section{JEREM, ERZSÉBET}

1968 The Late Iron Age Cemetery of Szentlörinc. Acta Archaeologica Academiae Scientiarum Hungaricae 20, 159-208.

1973 Zur Geschichte der späten Eisenzeit in Transdanubien. Späteisenzeitliche Grabfunde von Beremend. Acta Archaeologica Academiae Scientiarum Hungaricae 25, 65-86.

1974 Handelsbeiehungen zwsichen der Balkanhalbinsel und dem Karpatenbecken im IV. und V. Jahrhundert v. u. Z. In: Chropovský, B. (Hrsg.): Symposium zu Problemen der jüngeren Hallstattzeit in Mitteleuropa. Bratislava, 229-242.

1981 Zur Späthallstatt- und Frühlaténezeit in Transdanubien. In: Eibner, C.-Eibner, A. (Hrsg.): Die Hallstattkultur. Bericht über das Symposium in Steyr 1980 aus Anlaß der internationalen Ausstellung des Landes Oberösterreich. Linz, 105-136.
KemenCzei, Tibor

2012 Angaben zur Kenntnis der Eisenzeit in der Südwesthälfte des Karpatenbeckens. Acta Archaeologica Academiae Scientiarum Hungaricae 63, 317-349. DOI: https://doi.org/10.1556/ aarch.63.2012.2.3

KovaČEVIĆ, SAŠA

2007 Karakteristični nalazi kasnohalštatskog naselja u Zbelavi kod Varaždina i fibula tipa Velem (Characteristic Finds from the late Hallstatt Settlement at Zbelava near Varaždin and a Velemtype Fibula). Prilozi Instituta za arheologiju u Zagrebu 24, 89112.

2008 Osvrt na strukturu i keramičku proizvodnju kasnohalštatskog naselja u Zbelavi kod Varaždina (A look at the structure and ceramic production of the late Hallstatt settlement in Zbelava near Varaždin). Prilozi Instituta za arheologiju u Zagrebu 25, $47-80$.

Ladefoged, Thegn N.-Gemmell, Caleb-McCoy, MarkJorgensen, Alex-Glover, Hayley-Stevenson, ChristopherO'NeALE, Dion

2019 Social network analysis of obsidian artefacts and Māori interaction in northern Aotearoa New Zealand. PLoS ONE 14(3): e0212941. DOI: https://doi.org/10.1371/journal.pone. 0212941

LJUŠTINA, MARIJA

2010 The Late Hallstatt Communities in the Serbian Part of the Danube Basin. In: Berecki, S. (ed.): Iron Age Communities in the Carpathian Basin. Proceedings of the International Colloquium from Târgu Mureş 9-11 October 2009. Bibliotheca Mvsei Marisiensis - Seria Archaeologica 2. Cluj-Napoca 2010, 59-78.

LOŽNJAK DizDAR, DARIA

2015 Slatina/Berezine - Early Iron Age graves in Central Podravina. In: Gutjahr, Ch.-Tiefengraber, G. (Hrsg.): Beiträge zur Hallstattzeit am Rande der Südostalpen, Akten des 2. Wildoner Fachgespräches am 10. und 11. Juni 2010 in Wildon/Stmk. Internationale Archäologie - Arbeitsgemeinschaft, Tagung, Symposium, Kongress 19. Rahden/Westf., 29-43.

Majnarić-Pandžić, Nives

1973 Vinkovci kod Silosa - kasnohalštatski grobovi (Vinkovci-Silos - Late Hallstatt Age graves). Arheološki Pregled 15, 39-40.

2003 Ein späthallstattzeitliches Gräberfeld in Vinkovci (Nordostkroatien) und das Problem eines neuen Phänomens der Pferdausstattung in diesem Gebiet. Germania 81, 481-511.

2009 On the South Pannonian Population in the Late Iron Age. In: Tiefengraber, G.-Kavur, B.-Gaspari, A. (eds): Keltske študija II Studies in Celtic Archaeology Papers in honour of Mitja Guštin. Montagnac, 235-246.

Marton, Erzsébet-Regenye, Judit

2005 Fortified site from the Late Bronze-Late Iron Age at lake Balaton in Tihany-Óvár: A rescue excavation in Hungary, May 2000. In: Cahen-Delhaye, Anne (red.): Sessions générales et posters: (12) General sessions and posters. Actes du 14ème Congrès UISPP, Université de Liège, Belgique, 2-8 septembre 2001. Section 12. Âge du fer en Europe. The Iron Age in Europe. British Archaeological Reports - International Series 1378. Oxford, 45-52.

Mazzucato, Camilla

2019 Socio-Material Archaeological Networks at Çatalhöyük a Community Detection Approach. Frontiers in Digital Humanities 6:8. DOI: https://doi.org/10.3389/fdigh.2019.00008

Márton, Lajos

1933 A korai La Tene-kultúra Magyarországon (Die Frühlatenezeit in Ungarn). Archaeologia Hungarica 11. Budapest. 


\section{МЕДОВИЋ, ПРЕДRАГ}

1990 Прилог проучавањз гвозденог доба у Срему (Contributions to the research of the Early Iron Age in Srem). Starinar 40-41, 159-164.

Medović, Predrag-Hänsel, Bernhard

2006 Die Srem Gruppe - Nekropolen bei den Siedlungen der BosutGruppe. In: Tasić, N.-Grozdanov, C. (eds): Homage to Milutin Garašanin. Beograd, 489-512.

Metzner-Nebelsick, Carola

2002 Der „Thrako-Kimmerische“ Formenkreis aus der Sicht der Urnenfelder- und Hallstattzeit im südöstlichen Pannonien. Vorgeschichtliche Forschungen 23. Rhaden/Westf.

2017 At the crossroads of the Hallstatt East. In: Schumann, R.-van der Vaart-Verschoof, S. (eds): Connecting Elites and Regions. Perspectives on contacts, relations and differentiation during the Early Iron Age Hallstatt C period in Northwest and Central Europe. Leiden, 349-379.

2019 Fremde Frauen in Frög, In: Hye, S.-Töchterle, U. (Hrsg.): UPIKU:TAUKE. Festschrift für Gerhard Tomedi zum 65. Geburtstag. Universitätsforschungen zur prähistorischen Archäologie 339. Bonn, 361-372.

Mills, Barbara. J.-Roberts JR., John M.-Clark, Jeffery J.-HaAs Jr., William. R.-Huntley, Deborah-Peeples, Matthew A.Borck, Lewis-Ryan, Susan C.-Trowbridge, Meghan - Breiger, RONALD L.

2013 The dynamics of social networks in the Late Prehispanic US Southwest. In: Knappett, C. (ed.): Network analysis in archaeology: New approaches to regional interaction. Oxford, 181-202.

Molnár, GÁBor-TímÁr, GÁBOR-BisZaK, ElőD

2014 Can the First Military Survey maps of the Habsburg Empire (1763-1790) be georeferenced by an accuracy of 200 meters? Nemzetközi Térképészeti Társaság (ICA, International Cartographic Association) Digitális Technológiák Alkalmazása a Térképészeti Örökségben Bizottságának (Commission on Digital Technologies in Cartographic Heritage) 9, angol nyelvű műhelybeszélgetése. Budapest, 2014 Szeptember 4-5. Budapest, 127-132. DOI: https://doi.org/10.13140/2.1.1447.8724

Newman, Mark

2010 Networks. An Introduction. Oxford.

O'SHEA, John M.

2011 A River Runs Through It: Landscape and the Evolution of Bronze Age Networks in the Carpathian Basin. Journal of World Prehistory 24:2/3, 161-174. DOI: https://doi. org/10.1007/s10963-011-9046-6

Östborn, Per-Gerding, Henrik

2014 Network analysis of archaeological data: a systematic approach. Journal of Archaeological Science 46, 75-88. DOI: https://doi. org/10.1016/j.jas.2014.03.015

ПАЛАВЕСТРА, АЛЕКСАНДАР

1984 Кнежевски гробови старијег гвозденог доба на централном Балкану. Београд.

Parkinson, William A.

Tribal boundaries: Stylistic variability and social boundary maintenance during the transition to the Copper Age on the Great Hungarian Plain. Journal of Anthropological Archaeology 25:1, 33-58. DOI: https://doi.org/10.1016/j. jaa.2005.06.002

Patek Erzsébet

1968 Die Urnenfelderkultur in Transdanubien. Archaeologia Hungarica 44. Budapest.

Petrić, Hrvoje-Tamás, Enikő Anna-Lóczy, Dénes

2019 Flood History and River Regulation. In: Lóczy, D. (ed.): The Drava River. Environmental Problems and Solutions. Springer
International Publishing, 105-124, DOI: https://doi. org/10.1007/978-3-319-92816-6

Potrebica, Hrvoje

2008 Contacts between Greece and Pannonia in the Early Iron Age with Special Concern to the Area of Thessalonica. In: Biehl, P. F.-Rassamakin, Y. Ya. (eds): Import and Imitation in Archaeology. Langenweißbach, 187-212.

Potrebica, Hrvoje-Dizdar, Marko

2002 Prilog poznavanju naseljenosti Vinkovaca i okolice u starijem željeznom dobu (A Contribution to the Understanding Continuous Habitation of Vinkovci and its Surroundings in the Early Iron Age). Prilozi Instituta za arheologiju u Zagrebu 19, 79-100.

2014a Late Hallstatt and Early La Tène Gold and Silver Beads in Southeast Pannonia. In: Gosden, Ch.-Crawford, S.Ulmschneider, K. (eds): Celtic Art in Europe - Making Connections. Essays in honour of Vincent Megaw on his 80th birthday. Oxford, 152-158.

2014b Changing Identities of the Iron Age Communities of Southern Pannonia. In: Popa, C. N.-Stoddart, S. (eds): Fingerprinting the Iron Age. Approaches to Identity in the European Iron Age. Integrating South-Eastern Europe into the Debate. Oxford, 123-141.

Prignano, Luce-Morer, Ignacio-Diaz-Guilera, Albert

2017 Wiring the Past: A Network Science Perspective on the Challenge of Archeological Similarity Networks. Frontiers of Digital Humanities 4(13), DOI: https://doi.org/10.3389/ fdigh.2017.00013

Schortman, Edward M.-Urban, Patricia A.

1987 Modeling Interregional Interaction in Prehistory. Advances in Archaeological Method and Theory 11, 37-95.

\section{SCHUMANN, ROBERT}

2015 Status und Prestige in der Hallstattkultur. Münchner Archäologische Forschungen 3. Rahden/Westf.

\section{Soós, BENCE}

2020 The Late Hallstatt Age Burials of Southern Transdanubia and a Missing Link. Acta Archaeologica Academiae Scientiarum Hungaricae 71:2, 409-442. DOI: https://doi.org/10.1556/ 072.2020 .00011

2021 Middle Iron Age Cemetery from Alsónyék, Hungary. Dissertationes Archaeologicae 3/8, 49-105. DOI: https://doi. org/10.17204/dissarch.2020.49

Szabó, MikLós

2012 Celtes et Pannons dans le Sud-Est de la Transdaubie. Acta Archaeologica Academiae Scientiarum Hungaricae 63, 351366. DOI: https://doi.org/10.1556/aarch.63.2012.2.4

Szeniczey, Tamás-Hajdu, Tamás

2021 Results of the analysis of the Early Iron Age human remains unearthed at Alsónyék, Hungary: Appendix. Dissertationes Archaeologicae 3/8, 107-110. DOI: https://doi.org/10.17204/ dissarch.2020.107

СРејовић, ДваГослАв-ВҮКАДИН, ОБРенИјА

1983 Благо из Крушевице, Рашка Баштина 3, 7-18.

Tecco Hvala, Sneža

2012 Magdalenska gora. Družbena struktura in grobni rituali železnodobne skupnosti (Magdalenska gora. Social structure and burial rites of the Iron Age community). Opera Instituti Archaeologici Sloveniae 26. Ljubljana.

Tecco Hvala, Sneža

2017 Molnik pri Ljubljani v železni dobi (The Iron Age site at Molnik near Ljubljana). Opera Instituti Archaeologici Sloveniae 36. Ljubljana. DOI: https://doi.org/10.3986/ 9789610503750 
TERŽAN, BIBA

1977a Certoška fibula (Die Certosfibel). Arheološki vestnik 27, 317443.

1977b O horizontu bojevniških grobov med Padom in Donavo v 5. in 4. stol. pr. n. št. (Horizon of Warrior Tombs found in the Fifth and Fourth Centuries B.C. in the Territory between the Po and the Danube). In: Guštin, M. (eds): Keltske študije. Posavski muzej Brežice 4. Brežice, 9-21.

1990 Starejša železna doba na slovenskem Štajerskem (The Early Iron Age in Slovenian Styria). Katalogi in monografije 25. Ljubljana.

1995 Handel und soziale Oberschichten im früheisenzeitlichen Südosteuropa. In: Hänsel, B. (Hrsg.): Handel, Tausch und Verkehr im Bronze- und früheisenzeitlichen Südosteuropa. Prähistorische Archäologie in Südosteuropa 11/ SüdosteuropaSchriften 17. Berlin-München, 81-159.

1998 Auswirkungen des skythisch geprägten Kulturkreises auf die hallstattzeitlichen Kulturgruppen Pannoniens und des Ostalpenraumes. In: Hänsel, B.-Machnik, J. (Hrsg.): Das Karpatenbecken und die osteuropäische Steppe. Prähistorische Archäologie in Südosteuropa 12 / Südosteuropa-Schriften 20. Leidorf, 511-560.

\section{TruhelKa, Ćiro}

1904 Der vorgeschichtliche Pfahlbau im Savebette bei Donja Dolina. Wissenschaftliche Mitteilungen aus Bosnien und der Herzegowina 9, 3-170.

VASIĆ, RASTKO

1971 The openwork belts and the Early Iron Age Chronology of the northern Balkans. Archaeologia Jugoslavica 12, 1-13.

1983 A Contribution to the Study of "Illyrian" Helmets in North Yugoslavia, Archaeologia Jugoslavica 22/23, 76-80.

1999 Die Fibeln im Zentralbalkan. Prähistorische Bronzefunde XIV/12. Stuttgart.

2001 Gold and silver in Iron Age Serbia. Archaeologia Bulgarica 5:3, 23-28.

2010 Reflecting on Illyrian helmets. Starinar 60, 37-55. DOI: https:// doi.org/10.2298/STA1060037V

Yu, Shi-Yong-Chen, Xue-Xiang-Fang, Hui

2019 Inferring inequality in prehistoric societies from grave sizes: a methodological framework. Archaeological and Anthropological Sciences 11, 4947-4958. DOI: https://doi.org/10.1007/ s12520-019-00845-0

\section{Folyók mentén? Csoportidentitás, interakciók és a folyók szerepe a késő Hallstatt-kori dél-pannoniai régióban}

\section{Soós Bence}

Nehezen vitatható, hogy a vaskori Észak-Balkánon a Száva völgye kiemelkedő jelentőségű kereskedelmi és kommunikációs útvonalat jelentett. A Kr. e. 6. század végének és Kr. e. 5. század elejének összefüggésében a Certosa fibulák elterjedése alapján alkothatunk képet arról, hogy a délkelet-alpi területek és az észak-balkáni vidékek közösségei milyen módon alakítottak ki és tartottak fenn nagy távolságokat átívelö kapcsolatokat. Az utóbbi évtizedekben látványosan bővülő dél-dunántúli forrásanyagnak köszönhetően lehetőség mutatkozik annak felderítésére, hogy a vélhetőleg hasonlóan fontos szereppel bíró Duna milyen szerepet játszhatott ugyanebben az időszakban. Jelen tanulmány célja annak vizsgálata, hogy a Kárpát-medence déli területeinek Kr. e. 6. század végi és Kr. e. 5. század eleji temetkezései alapján a térség közösségei között milyen kapcsolatok és interakciós hálózatok rajzolhatók fel.

Open Access. A cikk a Creative Commons Attribution 4.0 International License (https://creativecommons.org/licenses/by/4.0) feltételei szerint publikált Open Access közlemény, melynek szellemében a cikk bármilyen médiumban szabadon felhasználható, megosztható és újraközölhető, feltéve, hogy az eredeti szerző és a közlés helye, illetve a CC License linkje és az esetlegesen végrehajtott módosítások feltüntetésre kerülnek. (SID_1) 